\title{
A review on the effects of antimicrobials use in cultures of planktonic organisms: a procedure for ecological experiments
}

\author{
Vanessa Ochi Agostini ${ }^{1,3,4}$, Laís Fernanda De Palma Lopes ${ }^{1,3,5}$ \\ Alexandre José Macedo ${ }^{2}$ \& Erik Muxagata ${ }^{1}$ \\ ${ }^{1}$ Laboratório de Zooplâncton, Instituto de Oceanografia, Universidade Federal do Rio Grande \\ Rio Grande, RS, Brasil \\ ${ }^{2}$ Laboratório de Biofilmes e Diversidade Microbiana, Faculdade de Farmácia and Centro de Biotecnologia \\ Universidade Federal do Rio Grande do Sul, Porto Alegre, RS, Brasil \\ ${ }^{3}$ Programa de Pós-graduação em Oceanografia Biológica, Schollarship from \\ Conselho Nacional de Desenvolvimento Científico e Tecnológico (CNPq) \\ ${ }^{4}$ Laboratório de Microcontaminantes Orgânicos e Ecotoxicologia Aquática \\ Postdoctoral fellow from Coordenação de Aperfeiçoamento de Pessoal de Nível Superior at \\ Programa de Pós-Graduação em Oceanologia, IO, FURG \\ ${ }^{5}$ Programa de Pós-graduação em Ciências da Engenharia Ambiental, Schollarship from CAPES \\ Núcleo de Ecotoxicologia e Ecologia Aplicada, Universidade de São Paulo, São Carlos, SP, Brasil \\ Corresponding author: Vanessa Ochi Agostini (voagostini@gmail.com)
}

\begin{abstract}
Many questions about the role of planktonic organisms remain unanswered because of the difficulty in obtaining a medium where bacteria and fungi are not present. Moreover, an excess load of these microorganisms in phytoplankton cultures and zooplankton organisms may cause nutrient competition or diseases and consequently the death of the organisms of interest. For this reason, we reviewed several methods that have been used to obtain axenic planktonic cultures through specific metabolic inhibitors, such as antibiotics and antifungal agents. From 1940 to 2016, most research was related to microalgae and crustacean's cultures, with the antimicrobials: penicillin, streptomycin, chloramphenicol, oxytetracycline, neomycin and nystatin being the most frequently used. The studies that applied antimicrobials agents to planktonic cultures were mainly focused on being able to culture them and to answer questions about the role of bacteria in aquatic communities without previous testing their effectiveness or their effects on non-target organisms. Therefore, this review sought to determine the correct use of antimicrobials in cultures of planktonic organisms to prevent bacterial and fungal growth, without causing damage to non-target organisms and may assist in the implementation of ecologically-oriented scientific experiments where bacterial and/or fungal inhibition is necessary.
\end{abstract}

Keywords: aquaculture; artificial aquatic systems; bacterial and fungal contamination; hypothesis test; production of algae; production of invertebrates

\section{INTRODUCTION}

Plankton is the term used for all living organisms floating or drifting in the water column that have little or no ability to swim against currents (Haeckel, 1893), including virus (virioplankton), bacteria (bacterioplankton), filamentous fungi and yeasts (mycoplankton), microalgae (phytoplankton) and phagotrofic organisms (zooplankton) (Johnson \& Allen, 2012). These organisms, as a whole, play a vital role in the food chain (classical and microbial loop), in some cases as prey and in others as predators (Hopcroft \& Roff, 1998), maintaining the balance of aquatic populations and cycling nutrients in this environment (biochemical cycles) (Calbet \& Saiz, 2016).

In addition, plankton plays a key role in benthicpelagic coupling, marine snow formation and biological pump (Schnack-Schiel \& Isla, 2005; Turner, 2015;

Corresponding editor: Eduardo Ballester 
Agostini et al., 2018). It can also be used as biological indicators of water masses, ocean currents, pollution and climate changes (Reid \& Edwards, 2001; Johnson $\&$ Allen, 2012). For this reason, there is great interest in understanding how the processes involving the planktonic community work, and how these organisms intereact with other organisms, being the phytoplankton and zooplankton the groups most studied, usually through the establishment of laboratory cultures.

Laboratory cultivation has been established in order to answer a series of questions about the biology and ecology of these organisms, facilitating genetic, cytology, morphology, physiology, development and taxonomy studies, as well as intra and inter-specific interaction studies (Trottet et al., 2011). Furthermore, planktonic organisms are commonly cultivated intensively for use in the aquaculture sector (Schipp et al., 1999), principally as the live food of commercial species of fish, mollusks and crustaceans (Creswell, 2010). However, when at high densities these cultures result in large loads of waste and organic matter (Olafsen, 1993), favoring the proliferation of virioplankton, mycoplankton and particularly free and/or adhered bacterioplankton, which can benefit or harm the culture, depending on the researcher aim.

\section{Effects of bacteria and fungi in cultures}

In aquaculture, for example, the biofloc tec (BFT) system comprises an association (aggregates) of bacteria, phytoplankton, fungi, virus and particulate organic matter, as well as bacterial grazers which benefit shrimp culture (Hargreaves, 2006). These aggregates or biofilms (bacteria systematically arranged in a self-produced polymeric matrix) (Vasudevan, 2014) that develop in the walls of the production tanks of crustaceans and fish reduce the cost of production by minimizing the overload of waste components, consequently reducing water exchange (Pandey et al., 2014).

Even though bacteria in BFT and biofilm in tanks formation can be considered to be beneficial in aquaculture, it is notable that in small-scale laboratory cultures, bacterial loads at high densities may result in the mortality of planktonic organisms (e.g., phytoplankton and zooplankton) (Shishlyannikov et al., 2011). In the absence of dense organic matter, such as those in laboratory cultures, pathogenic microorganisms can adhere to cultured organisms (Torkildsen \& Magnesen, 2004), and the intense aeration necessary to establish the BFT (Avnimelech, 2007) is unfeasible for cultures of smaller organisms, since the turbulence caused by the strong aeration could stress the organisms. Even if the laboratory culture has a high concentration of solids to which the microorganisms can adhere, this will cause a drastic consumption and reduction of dissolved oxygen because the volume of the medium is significantly lower than that of commercial cultures (Emerenciano et al., 2012). Also, the biofilm can eventually colonize the body and appendages of the cultivated organisms, resulting in a multitude of consequences for the basibiont, like: increased weight and friction, impeded trans-epidermal exchanges, altered color, smell and contour, resulting in multiple consequences. These changes may lead to the loss of buoyancy and motility, impair mating or even cause a substantial shift in the interactions among species (Wahl et al., 2012).

Both commercial and laboratory cultures can stimulate the selection and growth of opportunistic bacteria (Olafsen, 1993), resulting in diseases (Alday et al., 2006), lower production (Lipton et al., 2003), and consequently even the death of algae, invertebrates or fish (Wyban \& Sweeney, 1991). The increased occurrence of diseases in aquatic species of economic interest due to the rapid multiplication of pathogens has resulted in significant losses in aquaculture, affecting the development of this sector in many countries (Pillay $\&$ Kutty, 2005). These diseases were principally caused by pathogenic microorganisms belonging to the bacterioplankton, mycoplankton, phytoplankton and protozoans (Uriarte et al., 2001). Among these microorganisms, the bacterioplankton is the one that can cause the most harm to aquatic species. Vibriosis and photobacteriose are the two most common types of bacterial diseases that can afflict marine, estuarine and sometimes freshwater farming systems and are principally responsible for the greatest impacts already reported in aquaculture (Defoirdt et al., 2007). In addition to the damage posed by the presence of bacterioplankton and mycoplankton in cultures, these microorganisms also interfere in aquatic scientific experiments, generating methodological problems that will be reflected on results (Spencer, 1952; Yetka \& Wiebe, 1974), or making it impossible to test hypothesis about the role of bacteria and fungi in an ecosystem or community (DeLorenzo et al., 2001; Trottet et al., 2011).

\section{Solutions for microbial control in cultures}

Despite many years of research, bacterial and fungal loads are still a primary concern in the production and culture of planktonic organisms (Torkildsen \& Magnesen, 2004) with several methods and techniques developed in an attempt to inhibit bacterial and fungal growth in cultures. According to Couch (1939) and Vieira (1977), the control of temperature, inoculum size, $\mathrm{pH}$, the organic content of the medium, washing the cells (using filtration and centrifugation) and 
reisolation, are the main techniques used to inhibit and/or eliminate bacteria and fungi from cultures. Furthermore, these microorganisms can be controlled through sterilization by ultraviolet light (UV) (Rentachler et al., 1941; Alexandre et al., 2008), membrane filtration (Bobbitt \& Betts, 1992; Zhou et al., 2011), autoclaving the water (Ferris \& Hirsch, 1991; Creswell, 2010), detergent (McCracken, 1989) or through chlorination (Creswell, 2010; Liu et al., 2012). These methods can be used singly or in combination.

However, when the research involves the production and/or culture of live organisms, it is difficult to avoid contamination of sterile water through the air because microalgae or zooplankton cultures/production involve transferring and/or handling organisms at distinct time intervals (Lourenço, 2006; Agostini, 2014; Agostini et al., 2016).

Currently, the use of probiotics to inhibit the growth of pathogenic bacteria has been proposed as an important nutritional factor influencing gastrointestinal physiology and function in aquaculture (Diplock et al., 1999), and it was defined as a live microbial feed supplement that could beneficially affect the host animal by improving its intestinal balance (Fuller, 1989). However, these measures have rarely, if ever, completely prevented the incidence of infectious diseases in farm animals. According to Alday et al. (2006), with the possible exception of ranching, some degree of the antimicrobial cover has been necessary for all animal production systems with probiotics. Antimicrobial agents can be defined as natural, semisynthetic or as synthetic substances that can kill (bactericides and fungicides) or inhibit the growth of microorganisms (bacteriostatic, fungistatic), principally based on the action mechanism and concentration dose (Dixon, 2000). After the discovery of penicillin by Fleming in 1928, antibiotics have become important drugs for human and animal welfare.

Antibiotics should be safe (non-toxic) for the host, allowing their use as chemotherapeutic agents for the treatment of infectious bacterial diseases. In addition to their use in human and veterinary, antimicrobials are also used in cultured animals for human consumption, and their use can be categorized as therapeutic, prophylactic or metaphylactic (Serrano, 2005). According to Shaw et al. (1994) and Campa-Córdova et al. (2006), there are advantages to the application of antimicrobials to the control of microbial density in culture mediums relative to other methods, and the main ones include the ease of handling and implementation, as well as the maintenance of its effect on the artificial environment. Shishlyannikov et al. (2011) and Agostini et al. (2016) believe that the sole use of antimicrobials is possible to obtain bacteria and fungi-free cultures without damage to non-target organisms.

The importance of healthy and well-established cultures of planktonic organisms are a goal on a variety of scientific (biology and ecology) or economic studies focused on genetic, cytology, morphology, physiology, taxonomy, ecology and as a food source for aquaculture or human use. For this reason, we reviewed antibiotic and antifungal methods that have been used to obtain zooplanktonic and phytoplanktonic cultures free of bacterioplankton and mycoplankton. These procedures are widely dispersed in the literature. We now summarize them to establish an accessible guide to new scientists about the use of antimicrobials in the culture medium of planktonic organisms for i) assisting ecology studies to answer questions about the role of bacteria and fungi in aquatic communities, ii) enhancing or treating cultures of planktonic organisms used as food in aquaculture, and iii) facilitating biological studies (genetic, taxonomy, development, growth) preventing bacterial and fungal growth, without causing damage to non-target organisms.

\section{Antimicrobials in planktonic cultures: historic}

The use of prokaryote inhibitors (such as antibiotics) to control bacterial growth in cultures of planktonic organisms began in the 1940s, when penicillin was used to obtain bacteria-free cultures of the protozoan Tritrichomonas foetus (Riedmuller, 1928) (Ithaca \& Mahmoud, 1944), and their use increased after the discovery of streptomycin in 1943, tetracycline in 1945 and neomycin in 1949. Between 1950 until 1969 there was an increase in the number of studies on this topic (Fig. 1). A series of papers documented the negative correlation between bacterial density and survival, and development of mollusk larvae (Loosanoff \& Davis, 1963), leading to studies regarding the use of antibiotics in planktonic cultures of other organisms such as microalgae and crustaceans (Shaw et al., 1994; Agostini et al., 2016).

From the 1970s until 1999, the use of antimicrobials in cultures of planktonic organism cultures declined with the application of other chemicals to culture ponds due to the contamination of the environment, of the final product, or both (Collier \& Pinn, 1998) (Fig. 1). From 2000 onwards, the problems concerning the use of antibiotics in aquaculture continued. However, a new field of application arose with studies using antibiotics and/or antifungals to acquire controlled environments free of microorganisms, enabling the test of hypotheses involving the contribution of bacterioplankton and mycoplankton in aquatic communities (DeLorenzo et al., 2001; Fouilland et al., 2007; Trottet et al., 2011) (Fig. 1).

A review on this topic using specialized books (Ray, 1966; Walne, 1970; Roberts, 1972; Brown, 1973; Kinne, 


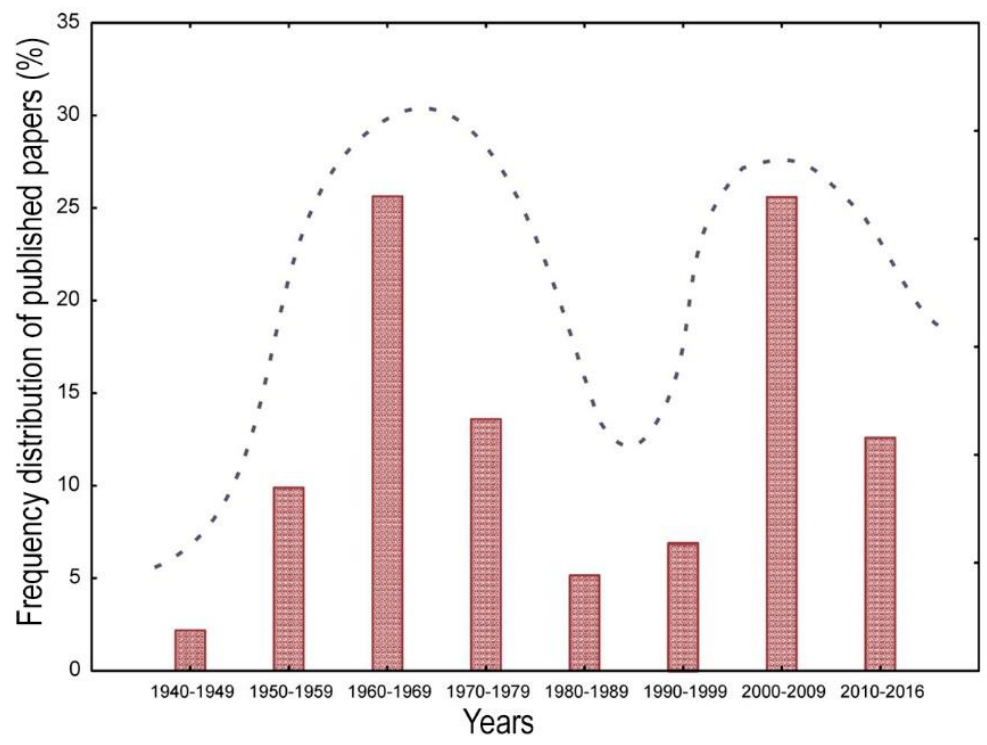

Figure 1. Frequency distribution of published papers (\%) that used antimicrobial agents in cultures of planktonic organisms between the years 1940 and 2016. The review was conducted using specialized books and ASFA database (http://www.fao.org/fishery/asfa/en) for papers published after 1971 using the keywords, plankton and antibiotics, plankton and antimicrobials, and aquaculture and bacteria-free. Google scholar (https://scholar.google.com.br) and CAPES periodic portal (http://www.periodicos.capes.gov.br) were also used to complement the information.

1977; Ukeles, 1977; Hetrick et al., 1981; Olafsen, 1993; Dixon, 2000; FAO/WHO, 2002; Pillay et al., 2005; Serrano, 2005; Alday et al., 2006; Lourenço, 2006; Creswell, 2010) and trough ASFA database (http://www.fao.org/fishery/asfa/en) using the keywords: plankton and antibiotics and antifungal, plankton and antimicrobials, aquaculture and bacteria-free returned 204 publications between 1940 and 2016 related to the use of antimicrobials in planktonic cultures. Google scholar (https://scholar.google.com.br) and CAPES periodic portal (http://www.periodicos.capes. gov.br) were also used to complement the information. From the review, it was seen that the decades starting on the 1960s and 2000 were the ones when most of the papers on this topic were published, corresponding each with $25.5 \%$ of the retrieved papers. The lowest number of publications goes back to the 1940s (2.2\%), at the beginning of this line of study, and when the associated problems in aquaculture arose in the 1990s (7\%). Fifty-seven antimicrobial agents were applied to plankton cultures between 1940 and 2016 (Annex 1).

The reviewed material indicated that the application of antibiotics in cultures not only ensures the inhibition of bacterial growth but also accelerates the development of the species of interest and increases their survival, when compared to control without antibiotics, reinforcing the idea that these substances may also be used as a tool for the hypothesis test. It was also observed that penicillin and streptomycin were the most often used in cultures of planktonic organisms; however, the percentage used about published works has decreased (Fig. 2), probably due to the discovery/formulation of new antibiotics. Currently, there is increased use of chloramphenicol (Chloromycetin®), oxytetracycline and neomycin in studies. These antimicrobials, together with penicillin and streptomycin, are the five antibiotics that are most often used (Fig. 2) due to their greater efficiency in inhibiting the bacterial community (bacterioplankton) (Annex 2) and when used in combination, ensure a broad spectrum of bacterial inhibition. Thus, antimicrobials could be associated with peptides (tryptone), acids (oxolinic, nalidixic), surfactants (Tween-80) or detergents (Eggermont et al., 2014). Guillard (2005) recommends the addition of organic matter with low molecular weight (for example, $0.006 \mathrm{mg} \mathrm{L}^{-1}$ glucose) when using antibiotics because this will ensure the inhibition of the synthesis of the bacterial cell wall. If bacterial growth is not happening, antibiotic will only retain the inert cells; on the other hand, if the biosynthesis of cell walls were occurring, will result in fatal bacterial damage.

Some authors emphasize that when successfully inhibiting bacteria, the niche is usually occupied by filamentous fungi and/or yeasts, which, in most cases, also needs to be controlled by applying an antifungal to avoid ill effects to the organisms of interest (Agostini, 2014; Agostini et al., 2016). Considering that most fungal pathogens are secondary or opportunistic invaders, 

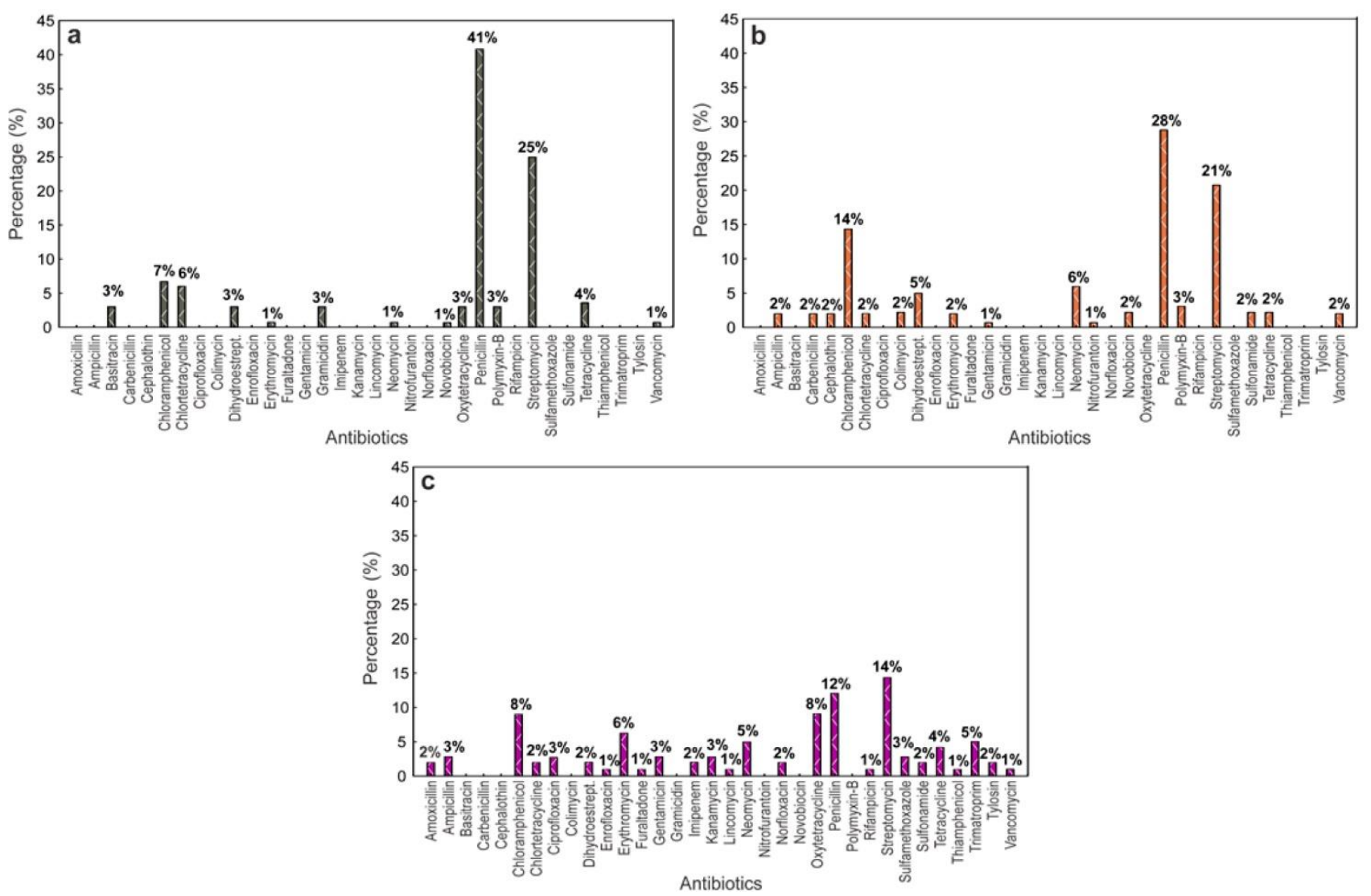

Figure 2. Percentage of published papers using a specific antibiotic formula in plankton cultures between 1940 and 2016. a) $1940-1959$, b) $1960-1989$, c) $1990-2016$.

which already belong to the biota of the water used, they can cause problems to farmed organisms (Leaño et al., 2005), e.g., mycoses, that have been considered one of the main factors related to economic losses in aquaculture (Zaror et al., 2004). Therefore, fungi can cause as much damage as bacteria; however fungi contamination is less common in marine than freshwater cultures (Lourenço, 2006).

The main antifungal agents used in cultures of planktonic organisms in the period between 1940 and 2016 included nystatin $(51 \%)$, cycloheximide $(30 \%)$, amphotericin-B (14\%) and candicidin (5\%) (Fig. 3). Many authors reported nystatin (Micostatin $®$ ) for the inhibition of fungal growth of filamentous fungi and yeasts in cultures (Lee et al., 1970; Sande \& Mandell, 1987; Groll et al., 1999; Wilkens \& Maas, 2012). This antifungal was first discovered in the early 1950s and is produced by the growth of the bacteria Streptomyces noursei. This antifungal bind to ergosterol in the plasmatic membrane of the fungal cell, forming pores that will lead to the loss of $\mathrm{K}$ as well as other small molecules to the medium, causing the death of the fungus (Lourenço, 2006). Cycloheximide is another often used antifungal, that will inhibit the protein synthesis in eukaryotes, by preventing the elongation of peptides through the transferal peptidase activity in ribosomes 60S (Lourenço, 2006). It is also produced by a bacteria, namely Streptomyces griseus, and was first used by Ray (1966) in cultures of the oyster Crassostrea virginica. Another antifungal, amphotericin-B (Fungizone $\left.{ }^{\circledR}\right)$, was originally extracted from Streptomyces nodosus in 1955, and employed by Lee et al. (1970) in combination with antibiotics in nematode cultures to inhibit filamentous fungi. Candicidin is an antifungal compound obtained from Streptomyces griseus and was only used by Provasoli \& Gold (1962) in cultures of the protozoan Crypthecodinium (=Gyrodinium) cohnii (Seligo) Javornicky, 1962 in combination with antibiotics. Both amphotericin B and candicidin have the same active principle of nystatin (Lourenço, 2006).

Combining antibiotics and antifungals could be an alternative to maintain or reduce the initial bacterial load and thus reducing the risk of handling contamination; however, using these substances to prevent bacterial and fungal infections should be done carefully to avoid harming the organisms of interest (Trottet et al., 2011). 


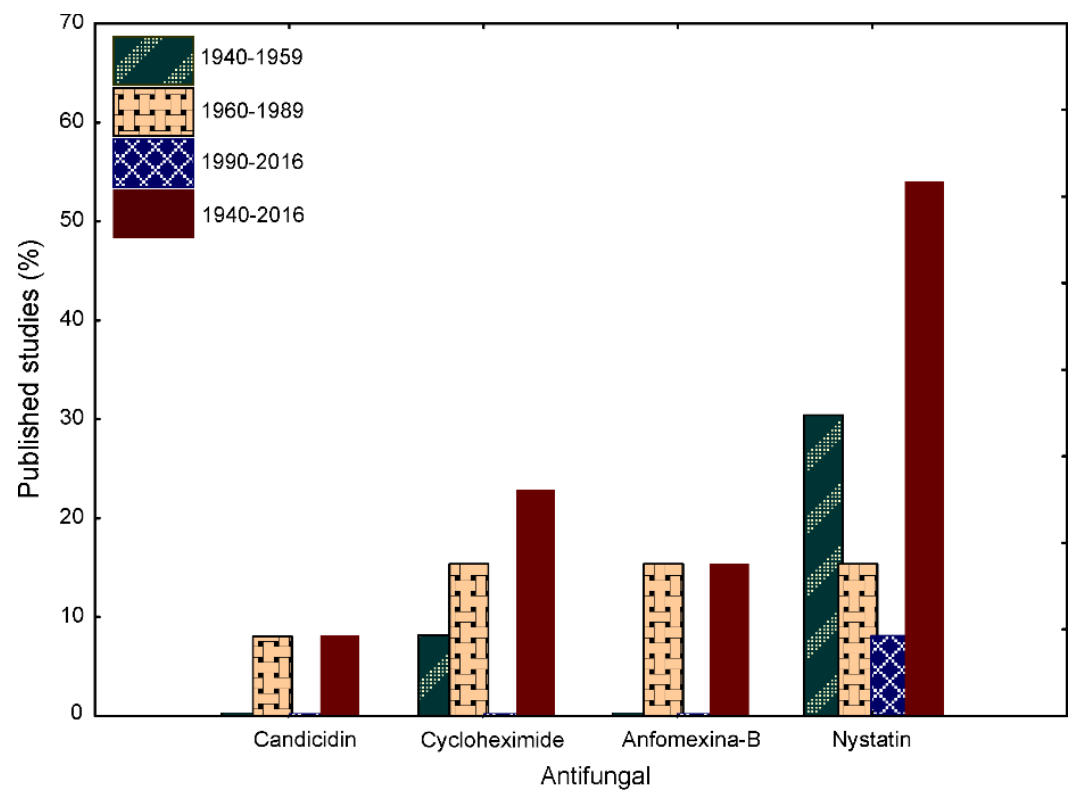

Figure 3. Percentage of antifungal used in plankton cultures between 1940 and 2016.

\section{Antimicrobials in planktonic cultures: major con- tributions}

Antimicrobial and other chemical agents have been used in conjunction with physical methods for many years to obtain axenic cultures of planktonic organisms. These procedures are widely dispersed in the literature since the 1940s. The present report summarizes this information for researchers that needs to minimize bacterial proliferation in planktonic cultures. The majority of the papers published between 1940 and 2016 regarding the areas of application for antimicrobial agents (Annex 3) were related to the inhibition of bacteria and fungi in cultures/production of phytoplankton (e.g., Campa-Córdova et al., 2006), followed by crustaceans (e.g., Agostini et al., 2016), hypothesis testing involving the planktonic community (e.g., Trottet et al., 2011), mollusks (e.g., Roberts et al., 2007), protozoan (e.g., Provasoli \& Gold, 1962), fish (e.g., Struhsaker et al., 1973), planktonic phase of seaweed (e.g., Kobayashi et al., 2003), periphyton (spores can be found in planktonic enviromental) (e.g., Vieira, 1977), Rotifera (e.g., Dougherty et al., 1960), Cnidaria (e.g., Claybrook \& Eakin, 1960), Cyanobacteria (e.g., Guo \& Chen, 2012), tychoplanktonic nematodes (zooplankton that oscillate periodicaly their position in water column) (e.g., Lee et al., 1970), Porifera (e.g., Borojevic, 1966), Platyhelminthes (e.g., Miller \& Johnson, 1959) and meroplanktonic Nemertea (zooplankton with a life cycle splited in pelagic and benthic enviromental) (e.g., Tuker, 1959) (Fig. 4).

We believe that the major use of antimicrobials in cultures of planktonic microorganisms i) allow/ improve the culture of planktonic organisms and ii) increase our knowledge about the role of bacteria and fungi in aquatic communities, testing hypothesis. Through the use of specific inhibitors in planktonic cultures, it is possible to i) eliminate or decrease bacteria and/or fungi load in the medium (Youn \& Hur, 2007), ii) inhibit the growth of pathogenic microorganisms (Castro-Mejía et al., 2007), iii) increase zooplankton and phytoplankton growth/survival (Campa-Córdova et al., 2006), development (Uriarte et al., 2001) and production (Agostini, 2014), and iv) reduce competition between phytoplankton and bacterioplankton (Youn \& Hur, 2007) and eliminate bacterial aggregates on microalgae wall's (Vieira, 1977). In phytoplankton and periphyton cultures, Vieira (1977) compare different methods and antimicrobials to maintain cultures of 12 different species of microalgae bacteria-free. He noted that the use of antibiotics boosted results. However, some criteria such as i) the evaluation of the physiological state of the algae cells to be treated (algal cells in the decline phase of growth are strongly attacked by bacteria, and are more sensitive to chemicals substances), and ii) the sensitivity of microalgae to antimicrobials (which varies according to the species, antibiotic, concentration and exposure time), should be followed to ensure the success of the method. Similarly, Youn \& Hur (2007) determined the extent of bacteria contamination and resistance to various antibiotics commonly used in different microalgal cultures (Chlorella ellipsoidea Gerneck, 1907; Isochrysis galbana Parke, 1949; Heterosigma akashiwo (Hada) Hada ex Hara \& Chihara, 1987; and Cyclotella didymus 


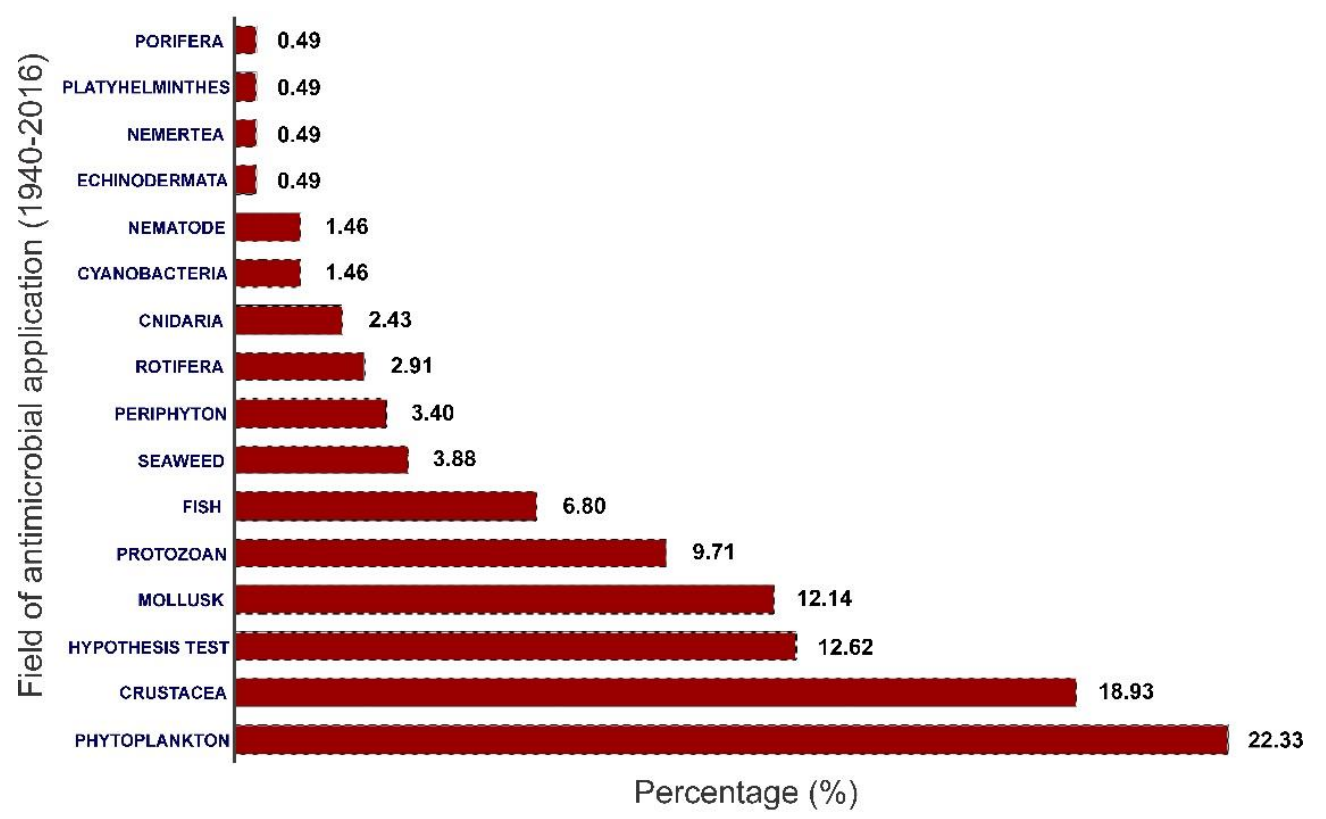

Figure 4. Field of study where antimicrobials were applied to inhibit the growth of bacterioplankton and/or mycoplankton.

and Thalassiosira alleni Takano, 1965). Seven different dosage levels of chloramphenicol, dihydrostreptomycin sulfate, neomycin, penicillin $\mathrm{G}$, streptomycin sulfate, penicillin $\mathrm{G}+$ streptomycin sulfate and penicillin $\mathrm{G}+$ streptomycin sulfate + chloramphenicol were added to each culture of microalgae. The authors verified that axenic culture of Bacillariophyceae and Dinophyceae was more difficult to obtain than those of Chlorophyceae and Haptophyceae because of them intricated external morphology. The efficiency of different antibiotics and their concentrations to obtain axenic cultures varied depending on the microalgal species used. The same conclusion was also observed by Vieira (1977).

For zooplankton cultures, the findings of Walne $(1956,1958,1963,1970)$ on molluscan production encouraged the application of antimicrobials in other zooplankton cultures (i.e., heterotrophic protozoans, rotifers, crustaceans and fish). This author used antibiotics (penicillin + streptomycin) to benefit oyster, through direct application in the culture medium and food (microalgae) of this molluscan in order to eliminate pathogenic microorganisms and increase the survival of oysters (More information in zooplankton cultures can be seen in Annex 2.2).

Regarding hypotheses tests, Müller (1969) initiated the use of antibiotics for test ecological relationship on the biofouling process, however involving just one planktonic invertebrate species (Hydractinia echinata (Fleming, 1828)). While Yetka \& Wiebe (1974) used specific inhibitors in an aquatic laboratory system, involving all community, without success because they concluded that the antibiotics tested could not be used to delineate bacterial respiration in mixed microbial communities. However, this initial approach leaded Sherr and collaborators in 1986 to estimate the grazing rates of heterotrophic nanoplankton on bacterioplankton using inhibitors, as well as Wheeler \& Kirchman (1986) to evaluate the utilization of inorganic and organic nitrogen by bacteria in marine systems applying antimicrobials in the medium, thus opening the way for other research using antimicrobials in different fields. For example, Maurin et al. (1997) evaluated the relationship between phytoplanktonic excretion and bacterial reassimilation in an oligo-mesotrophic lake, using antibiotics to get treatment without bacteria, making it possible to prove the hypothesis that bacterial heterotrophic reassimilated most of the products excreted by phytoplankton. Meanwhile, Bidle et al. (2003) experimented in paleoceanography area with treatment with antibiotics to prove that marine bacteria accelerate biogenic silica dissolution rates in the sea.

In aquatic ecology, the main contributions on the application of antimicrobials for hypothesis tests were the works of DeLorenzo et al. (2001) and Trottet et al. (2011). DeLorenzo et al. (2001) use of metabolic inhibitors (penicillin+streptomycin+neomycin+cycloheximide) to characterize ecological interactions of the com-munity (free-living and adherent heterotrophic bacteria, ciliate and flagellate) in an estuarine microbial food web proved their hypotheses that there are seasonal shifts in microbial food web structure and function related to the season. In their study, they showed the important role of microbial loops in driving 
primary and secondary production in estuaries, using antimicrobials as a tool. Trottet et al. (2011) selected, tested and compared the most commonly reported antibiotics to assess their effect on bacterial growth and functional diversity of natural communities and their efficiency involving phytoplankton and bacterioplankton interactions such as competition and mutualism, or lack of interaction between the different components of the microbial communities to study their relative importance in biogeochemical fluxes. They found that penicillin and streptomycin at a final concentration of $0.1 \mathrm{~g} \mathrm{~L}^{-1}$ each significantly reduced bacterial growth within two hours. They also reported that there was a greater impact on bacterial functional diversity when both antibiotics were mixed, and this mixture did not have any significant effect on the growth of selected cultured phytoplankton strains. The most interesting aspects of these works is the community level study (DeLorenzo et al., 2001) which differs from those that evaluated the interaction of bacterioplankton with only one functional group (i.e., phytoplankton) and the comparison of different antimicrobials (individually or in combination) (Trottet et al., 2011).

While in population level, Shaw et al. (1994) used antibiotics with success as tools to evaluate situations in which marine phytoplankton use chemical feeding deterrents to reduce or inhibit grazing by the copepod Tigriopus californicus (Baker, 1912). Whereas Tartarotti \& Torres (2009) used treatments with the antibiotic gentamicin $\left(50 \mathrm{~g} \mathrm{~L}^{-1}\right.$; applied at a concentration of $1 \mathrm{~mL} \mathrm{~L}^{-1}$ ) in cultures of the copepod Acartia tonsa Dana, 1849 to successfully test the hypothesis that bacteria affect the formation of the copepod exoskeleton. Although it is noteworthy that prokaryotic and eukaryotic inhibitors have been successfully used also to evaluate: i) the role of bacteria in the production of metabolites (Ringelberg \& Van Gool, 1998), ii) the role of microbes in the decomposition process (Tang et al., 2006), iii) phytoplankton-bacteria interactions (Hamdan \& Jonas, 2007), iv) competition for dissolved nitrogen (Fouilland et al., 2007), v) influence of bacterioplankton activities on nitrogen uptake rates (Tungaraza et al., 2003), vi) interaction on biofouling process (Roberts et al., 2007) and vii) the potential protein synthesis by bacteria (Tartarotti \& Torres, 2009).

\section{Adverse effects of antibiotic use on cultures}

Despite all these benefits, due to improper disposal, the development of bacterial resistance and ecological problems, the current trend is to reduce the use of antibiotics. Furthermore, import restrictions by the presence of residues in tissues of cultured organisms and possible damage to public health, result even in the banning and limitation of the use of these antimicrobials in many countries when used in cultures of organisms for human consumption (Defoirdt et al., 2007). Antimicrobial agents are usually administered to marine fish (Buschmann et al., 2012), and its feces containing unabsorbed antimicrobials and secreted antimicrobial metabolites in the environment of fish farming sites often retain their antimicrobial activity and can remain in the aquatic environment for variable periods (Burridge et al., 2010). For example, McCracken et al. (1976) established that the antibiotic trimethoprim could remain in the system for 77 days after the cessation of treatment. Therefore, environmental contamination can occur if the tank water is discharged into the environment within this period.

Antibiotics act as inducers of bacterial genes encoding mechanisms of drug resistance (Butaye et al., 2003) and the selection of antimicrobial-resistant bacteria in the marine environment could have detrimental impacts on animal and human health (Buschmann et al., 2012). Nevertheless, there is a hypothesis that antibiotics resistance varies between environments and regions, depending primarily on the selection pressure imposed on the ecosystem (Pereira et al., 2006), and the selection power is proportional to the exposure time of the bacteria to the antimicrobial (Aliabadi \& Lees, 2000).

Antibacterial agents have been frequently detected in sewage effluents, surface waters and groundwater (Ying \& Kookana, 2007) through the improper disposal of water with antimicrobial residues (by aquaculture, hospital, industrial and domestic sewage). According to Hektoen et al. (1995), a large portion of the antibiotics administered in farms (70-80\%) has been reported to reach the environment, promoting the impact of the disposal on the adjacent community. Møster (1986) observed detectable levels of antibiotic in blue mussels (Mytilus edulis) located $80 \mathrm{~m}$ from a fish farm where antibiotics were used. The ecological effects in the environment are related to the lack of biodegradation of these substances. Only a few of the compounds were partially biodegraded in aquatic systems (Kümmerer $e t$ al., 2000), accumulating in the water and sediment and this allows the appearance of resistant bacteria to affect the food chain directly (Kümmerer, 2003). For example, according to Lourenço (2006), continuous exposure to antibiotics generates damage with various extensions in microalgae. Thus, this author suggests only short-term treatments. Furthermore, it is reported in the literature that the use of antibiotics can cause in planktonic organisms: genetic mutations (Kumar, 1964; Droop, 1967), inhibiting the nuclear DNA synthesis in algae (Vieira, 1977), loss of color in microalgae and protozoa (Provasoli et al., 1948), 
inhibition of chloroplasts (Vieira, 1977) and mitochondrial synthesis (Lloyd, 1974) in algae, abnormalities in the morphology and behaviour of the clam larvae (Fitt et al., 1992), toxicity (Wollenberger et al., 2000) and inhibition of growth (Kviderova \& Henley, 2005).

As noted in section 1.2.1, the use of probiotics (live microorganisms that when administered in adequate amounts confer a health benefit for the organism cultivated, inhibiting possible pathogens) (FAO/WHO, 2002) can be a solution for large-scale cultures destined for human consumption, replacing the use of antimicrobials. Rego et al. (2012) observed that the concentration of Vibrio spp. on the water and postlarvae, shrimps of Litopenaeus vannamei were significantly reduced with the use of Bacillus spp. probiotic. Riquelme \& Avendaño-Herrera (2003), for example, used streptomycin/oxytetracycline + furaltadone to compare the efficiency of probiotics for the same species culture. Probiotics had the same results regarding mollusk survival than antibiotics; however, the antibiotic treatment decreased bacterial density more than probiotic treatment, being the most indicated for the hypothesis test, that requires a culture medium with minimum bacteria as possible. Still, short-time cultures without transfer of organisms and with low organic matter can be maintained without bacterial and fungal contamination by traditional methods (sterilization, chlorination or filtration of the culture medium), preferably maintaining the cultures covered (i.e., PVC film), but with light penetration, avoiding contamination via air, in order to maximize antimicrobial efficiency.

There are other chemical procedures for the purification of marine and freshwater cultures, particularly of microalgae, involving the use of bacteriostatic agents such as potassium tellurite $\left(\mathrm{K}_{2} \mathrm{TeO}_{3}\right)$ or sulfonamides, which oxidizes bacterial cells and prevents the synthesis of nucleic acids by bacteria, respectively. Besides the application of the enzyme lysozyme, iodine in alcoholic solution or ionic detergent (Triton and Tween), as well as of Dakin's solution ( 0.45 to $0.5 \%$ sodium hypochlorite $+4 \%$ boric acid) developed during the First World War (Lourenço, 2006). The problem with these methods is that they often need to be applied in conjunction with antimicrobial or accompanied by physical procedures (i.e., washing and centrifuging) to ensure its efficiency.

\section{Future directions: remarks and conclusion}

Planktonic organisms are involved in the major ecosystem processes in the aquatic community. However, ecological laboratory studies require precise and replicable protocols that allow the understanding of the biological and ecological factors that directly and indirectly affect a population or a community, respectively, without affecting organisms of interest. The application of antimicrobials in laboratory cultures of planktonic organisms seems to be an alternative to obtain responses at the population level or the community level without the microbial influence, although care must be taken to obtain accurate results. A pilot investigation on the characteristics and effects of antimicrobials should be conducted to obtain precise results, ensuring maximum efficiency of antimicrobials in the aquatic system. According to McCracken (1989), there is no overall applicable method for all species because every culture has different communities of microorganisms and the degree of sensitivity of organisms may show different responses to the same chemical. Thus, we have established remarks for the use of antimicrobials in planktonic cultures safely either for the hypothesis test or to obtain healthy cultures:

i) Penicillin, streptomycin, oxytetracycline and neomycin are the antibiotics most often used in planktonic cultures with success, individually or in combination and they must be prioritized in the choice, either for phytoplanktonic or zooplanktonic organisms.

ii) Note the tolerance of the organisms to the antimicrobial chosen. Give preference to antibiotic combinations of a broad spectrum, because studies indicate that they are more efficient than individual antimicrobials alone (Pappas \& Hoffmann, 1952; Kinne, 1977; Agostini et al., 2016). However, attention should be paid to the burnout effect among them. Speck et al. (1951) reported that chlortetracycline (Aureomycin $\left.{ }^{\circledR}\right)$ and oxytetracycline (Terramycin $\circledast$ ) antagonized the action of penicillin in cultures. Furthermore, the antagonistic effects between species that can minimize the effects of antibiotics used must also be checked. Tchan \& Gould (1961) found that bacteria tested alone were sensitive to some of these antibiotics, but not when associated with the blue-green algae, suggesting a protective effect of the algae.

iii) In the development of bacteria-free cultures, previous sterilization of the equipment, such as glassware and medium, will probably be beneficial, because this will reduce the initial bacterial load (Alexandre et al., 2008; Creswell, 2010; Zhou et al., 2011). Cover the cultures (e.g., PVC film) could also be an alternative to avoid contamination.

iv) The stock solution of antimicrobials (diluted in distilled water) must be prepared, if possible, immediately before use; otherwise, it must be frozen after being filtrated trough sterilized filters $(0.2 \mu \mathrm{m})$. Two variables define the final result: the dose of the antimicrobial and the exposure time (Lourenço, 2006). 
v) Evaluate the effectiveness of the selected antibiotics through bacterial density estimated by checking the onset of action and its half-life in the culture medium.

vi) Test the antimicrobials previously in the salinity and culture medium of interest, since studies have shown that the variation of the salinity medium results in an increase of the toxicity of the chemical substances in invertebrates (Kwok \& Leung, 2005; Pedroso et al., 2007), due to alteration of the water content and concentration of inorganic ions (Ferguson \& Hogstrand, 1998).

vii) The use of the appropriate antibiotics will result in the inhibition of bacteria in the culture medium. However, this will likely cause an overgrowth of fungi, making it necessary to include a small concentration of a eukaryotic inhibitor in the combination after a previous sensitivity test. Tang et al. (2006), Agostini (2014), and Agostini et al. (2016) reported the prevalence of fungi when the bacterial load was reduced, suggesting the inclusion of an antifungal. We suggest the application of nystatin (the antifungal most often used in cultures), but in low concentration, because this inhibits eukaryotes organisms.

viii) There may be different sensitivities to the same treatment of antimicrobial between development stages of the same animal species; usually, earlier stages are more sensitive. For the adult mollusk Ostrea edulis Linnaeus, 1758 , for example, $0.25 \mathrm{~g} \mathrm{~L}^{-1}$ of streptomycin in combination to $50,000 \mathrm{IU} \mathrm{L}^{-1}$ of penicillin is applied in its culture medium (Walne, 1963), however for larval stages just $0.05 \mathrm{~g} \mathrm{~L}^{-1}$ of streptomycin $+50,000 \mathrm{IU} \mathrm{L}^{-1}$ of penicillin will be required (Walne, 1958). For egg culture of the barnacle Fistulobalanus albicostatus, Chen et al. (2007) suggest the use of $0.01 \mathrm{~g} \mathrm{~L}^{-1}$ of penicillin $+0.005 \mathrm{~g} \mathrm{~L}^{-1}$ of streptomycin, however for barnacle larvae of the same species it is advisable to use $0.02 \mathrm{~g} \mathrm{~L}^{-1}$ of penicillin $+0.03 \mathrm{~g} \mathrm{~L}^{-1}$ of streptomycin (Yoshimura et al., 2006). For this reason, even if the combination of antimicrobials has been utilized for the cultivation of an adult of a particular species, it is advisable to test this treatment with the development stage of interest.

ix) It is necessary to evaluate the water quality (ammonia, nitrite, nitrate, phosphate, sulfate) and estimate possible changes in the use of antimicrobials in culture medium caused by the withdrawal of bacteria. The bacterioplankton is responsible for nutrient cycling, and its removal could result in the accumulation of nutrients to toxic levels (Alongi, 1994; Silva et al., 2012).

$\mathrm{x})$ Make sure to process and appropriately dispose of the culture and the production medium with antimicrobials avoiding environmental contamination and/or bacteria resistance.
Even with the limitations in the application of antimicrobials in farming systems intended for human consumption, these substances have the potential to be used in controlled laboratory cultures of planktonic organisms intended to be used in bioassays, and also for testing hypotheses aimed at evaluating the contribution of the bacterial and/or fungal in the aquatic community (DeLorenzo et al., 2001; Trottet et al., 2011; Agostini et al., 2016). Therefore, with proper care, scientists may use these substances in scientific experiments where systems without bacterioplankton and/or mycoplankton contamination are needed to provide a better understanding of the real effect of the microbial community such as competition and mutualism, or the lack of interaction between the different components of the planktonic community. Besides, it could be used to assess the relative importance of these microorganisms in biofouling, marine snow, biogeochemical fluxes, microbial loop, benthic-planktonic coupling and the biological pump.

\section{ACKNOWLEDGMENTS}

The authors acknowledge the support of Federal University of Rio Grande and Conselho Nacional de Desenvolvimento Científico e Tecnológico (CNPq141217/2014-6) and PRONEM FAPERGS/CNPq 11/2014 (6/2551-000244-4).

\section{REFERENCES}

Agostini, V.O. 2014. Avaliação dos efeitos do uso de antimicrobianos em cultivos de plâncton marinho. Dissertação de Mestrado (Programa de Pós-Graduação em Oceanografia Biológica). Universidade Federal do Rio Grande, Brasil, 124 pp.

Agostini, V.O., Macedo, A.J. \& Muxagata, E.M. 2016. Evaluation of antibiotics as a methodological procedure to inhibit free-living and biofilm bacteria in marine zooplankton culture. Anais da Academia Brasileira de Ciências, 88(1): 733-746.

Agostini, V.O., Macedo, A.J. \& Muxagata, E.M. 2018. O papel do biofilme bacteriano no acoplamento bentopelágico, durante o processo de bioincrustação. Revista Liberato, 19: 23-41.

Alday, V., Guichard, B., Smith, P. \& Uhland, C. 2006. Towards a risk analysis of antimicrobial use in aquaculture. Antimicrobial use in aquaculture and antimicrobial resistance. Report of a Joint FAO/ WHO/OIE. Expert consultation on antimicrobial use in aquaculture and antimicrobial resistance, Seoul, 144 pp.

Alexandre, F.A.A., Faria, J.A.F. \& Cardoso, C. 2008. Avaliação da eficiência da radiação ultravioleta na 
esterilização de embalagens plásticas. Ciência e Agrotecnologia, 32: 1524-1530.

Aliabadi, F.S. \& Lees, P. 2000. Antibiotic treatment for animals, effect on bacterial population and dosage regimen optimization. International Journal of Antimicrobial Agents, 14: 307-313.

Alongi, D.M. 1994. The role of bacteria in nutrient recycling in tropical mangrove and other coastal benthic ecosystems. Hydrobiologia, 285(1): 19-32.

Avnimelech, Y. 2007. Feeding with microbial flocs by tilapia in minimal discharge bio-flocs technology ponds. Aquaculture, 264: 140-147.

Bidle, K.D., Brzezinski, M.A., Long, R.A., Jones, J.L. \& Azam, F. 2003. Diminished efficiency in the oceanic silica pump caused by bacteria-mediated silica dissolution. Limnology and Oceanography, 48(5): 1855-1868.

Bobbitt, J.A. \& Betts, R.P. 1992. The removal of bacteria from solutions by membrane filtration. Journal of Microbiological Methods, 16(3): 215-220.

Borojevic, R. 1966. Étude expérimentale de la differenciation des cellules de l'êponge au cours de son développement. Developmental Biology, 14: 130-153.

Brown, C. 1973. The effects of some selected bacteria on embryos and larvae of the American oyster, Crassostrea virginica. Journal of Invertebrate Pathology, 21: 215-223.

Burridge, L., Weis, J.S., Cabello, F., Pizarro, J. \& Bostick, K. 2010. Chemical use in salmon aquaculture. A review of current practices and possible environmental effects. Aquaculture, 306: 7-23.

Buschmann, A.H., Tomova, A., López, A., Maldonado, M.A., Henríquez, L.A., Ivanova, L., Moy, F., Godfrey, H.P. \& Cabello, F.C. 2012. Salmon aquaculture and antimicrobial resistance in the marine environment. Plos One, 7(8): e42724.

Butaye, P., Cloeckaert, A. \& Schwarz, S. 2003. Mobile genes coding for efflux-mediated antimicrobial resistance in Gram-positive and Gram-negative bacteria. International Journal of Antimicrobial Agents, 22: 205-210.

Calbet, A. \& Saiz, E. 2016. Role of zooplankton in marine biogeochemical cycles: from fine scale to global theories. Journal of Plankton Research, 38(3): 690691.

Campa-Córdova, A.I., Luna-González, A., Ascencio, F., Cortés-Jacinto, E. \& Cáceres-Martínez, C.J. 2006. Effects of chloramphenicol, erythromycin and furazolidone on growth of Isochrysis galbana and Chaetoceros gracilis. Aquaculture, 260: 145-150.

Castro-Mejía, G., Castro-Barrera, T., ArredondoFigueroa, J.L., Castro-Mejía, J. \& de Lara, R. 2007. Antibiotics incorporation in Artemia franciscana nauplii, metanauplii, juveniles and adults, and their inhibitory action on Aeromonas hydrophila bacteria. Hidrobiológica, 17(1): 53-60.
Chen, P.-H., Chen, Y.-H. \& Chen, M. 2007. Effect of biofilm age and type on settlement of cyprids of the barnacle, Fistulobalanus albicostatus Pilsbry (Thoracica, Balanidae). Zoological Studies, 46(4): 521-528.

Claybrook, D.L. \& Eakin, R.E. 1960. Nutrition requirements for asexual reproduction of hydra. Journal of Experimental Zoology, 145: 179-190.

Collier, L.M. \& Pinn, E.H. 1998. An assessment of the acute impact of the sea lice treatment ivermectin on a benthic community. Journal of Experimental Marine Biology and Ecology, 230: 131-147.

Couch, J.N. 1939. Technic for collection, isolation, and culture of Chytrids. Journal of the Elisha Mitchell Scientific Society, 55: 208-214.

Creswell, L. 2010. Phytoplankton culture for aquaculture feed. Southern Regional Aquaculture Center, 5004: 16 pp.

Defoirdt, T., Boon, N., Sorgeloos, P., Verstraete, W. \& Bossier, P. 2007. Alternatives to antibiotics to control bacterial infections, luminescent vibriosis in aquaculture as an example. Trends in Biotechnology, 25: 472-479.

DeLorenzo, M.E., Lewitus, A.J., Scott, G.I. \& Ross, P.E. 2001. Use of metabolic inhibitors to characterize ecological interactions in an estuarine microbial food web. Microbial Ecology, 42: 317-327.

Diplock, A.T., Aggett, P., Ashwell, M., Bornet, F., Fern, E. \& Roberfroid, M. 1999. Scientific concepts of functional food science in Europe - consensus document. British Journal of Nutrition, 1: 1-28.

Dixon, B.A. 2000. Antibiotics. In: Stickney, R.R. (Ed.). Encyclopedia of aquaculture. John Wiley \& Sons, New Jersey.

Dougherty, E.C., Solberg, B. \& Ferral, D.J. 1960. Synxenic and attempted axenic cultivation of rotifers. Anatomical Record, 137: 350-351.

Droop, M.R. 1967. A procedure for routine purification of algal cultures with antibiotics. British Phycological Bulletin, 3: 295-297.

Eggermont, M., Tamanji, A., Nevejan, N., Bossier, P., Sorgeloos, P. \& Defoirdt, T. 2014. Stimulation of heterotrophic bacteria associated with wild-caught blue mussel (Mytilus edulis) adults results in mass mortality. Aquaculture, 431: 136-138.

Emerenciano, M., Cuzon, G., Goguenheim, J. \& Gaxiola, G. 2012. Floc contribution on spawning performance of blue shrimp Litopenaeus stylirostris. Aquaculture Research, 44: 75-85.

Food and Agriculture Organization (FAO) \& World Health Organization (WHO). 2002. Guidelines for the evaluation of probiotics in food. Report of a joint $\mathrm{FAO} / \mathrm{WHO}$ working group on drafting guidelines for 
the evaluation of probiotics in food. FAO \& WHO, Ontario, $11 \mathrm{pp}$.

Ferguson, E.A. \& Hogstrand, C. 1998. Acute silver toxicity to seawater-acclimated rainbow trout, Influence of salinity on toxicity and silver speciation. Environmental Toxicology and Chemistry, 17(4): 589593.

Ferris, M.J. \& Hirsch, C.F. 1991. Method for isolation and purification of cyanobacteria. Applied and Environmental Microbiology, 57(5): 1448-1452.

Fitt, W.K., Heslingab, G.A. \& Watsonb, T.C. 1992. Use of antibiotics in the mariculture of giant clams ( $F$. Tridactinidae). Aquaculture, 104: 1-10.

Fouilland, E., Gosselin, M., Rivkin, R.B., Vasseur, C. \& Mostajir, B. 2007. Nitrogen uptake by heterotrophic bacteria and phytoplankton in Arctic surface waters. Journal of Plankton Research, 29: 369-376.

Fuller, R. 1989. A review, probiotics in man and animals. The Journal of Applied Bacteriology, 66: 365-378.

Groll, A.H., Michkiene, D., Werner, K., Piscitelli, S. \& Walsh, T.J. 1999. High-performance liquid chromategraphic determination of liposomal nystatin in plasma and tissues for pharmacokinetic and tissue distribution studies. Journal of Chromatography B, 735: 51-62.

Guillard, R.R.L. 2005. Purification methods for microalgae. In: Andersen, R.A. (Ed). Algal culturing techniques. Elsevier, San Diego, pp.117-132.

Guo, R.X. \& Chen, J.Q. 2012. Phytoplankton toxicity of the antibiotic chlortetracycline and its UV light degradation products. Chemosphere, 87: 1254-1259.

Haeckel, E. 1893. Planktonic studies: a comparative investigation of the importance and constitution of the pelagic fauna and flora. Report of the U.S. Commisioner of Fish and Fisheries for 1889 to 1891 , pp. 565-641.

Hamdan, L. \& Jonas, R. 2007. The use of antibiotics to reduce bacterioplankton uptake of phytoplankton extracellular organic carbon (EOC) in the Potomac River estuary. Journal of Experimental Marine Biology and Ecology, 342: 242-252.

Hargreaves, J.A. 2006. Photosynthetic suspended-growth systems in aquaculture. Aquacultural Engineering, 34: 344-363.

Hektoen, H., Berge, J.A., Hormazabal, V. \& Yndestad, M. 1995. Persistence of antibacterial agents in marinesediments. Aquaculture, 133(3-4): 175-184.

Hetrick, F.M., Stephens, E., Lomax, N. \& Lutrell, K. 1981. A marine molluscan cell line. Technical Report, Maryland Sea Grant Program, 87 pp.

Hopcroft, R.R. \& Roff, J.C. 1998. Zooplankton growth rates, the influence of female size and resources on egg production of tropical marine copepods. Marine Biology, 132: 79-86.
Ithaca, Y. \& Mahmoud, A.H. 1944. Isolation of Trichomonas foetus (Riedmuller, 1928) in bacteriafree cultures by the use of penicillin. Annals of Tropical Medicine and Parasitology, 38: 219-222.

Johnson, W.S. \& Allen, D.M. 2012. Zooplankton of the Atlantic and Gulf coasts: a guide to their identification and ecology. Johns Hopkins University Press, Baltimore.

Kinne, O. 1977. Research cultivation. In: Kinne, O. (Ed.). Marine ecology, a comprehensive, integrated treatise on life in oceans and coastal waters. John Wiley \& Sons, New Jersey, pp. 579-1293.

Kobayashi, K., Kobiyama, A., Kotaki, Y. \& Kodama, M. 2003. Possible occurrence of intracellular bacteria in Pseudo-nitzschia multiseries, a causative diatom of amnesic shellfish poisoning. Fisheries Science, 69: 974978.

Kümmerer, K. 2003. Significance of antibiotics in the environment. Journal of Antimicrobial Chemotherapy, 52(1): 5-7.

Kümmerer, K., Al-Ahmad, A. \& Mersch-Sundermann, V. 2000. Biodegradability of some antibiotics, elimination of the genotoxicity and affection of wastewater bacteria in a simple test. Chemosphere, 40: 701-710.

Kumar, H.D. 1964. Streptomycin and penicillin-induced inhibition of growth and pigment production in bluegreen algae and production of strains of Anacystis nidulans resistant to these antibiotics. Journal of Experimental Botany, 15: 232-250.

Kviderova, J. \& Henley, W.J. 2005. The effect of ampicillin plus streptomycin on growth and photosynthesis of two halotolerant chlorophyte algae. Journal of Applied Phycology, (17): 301-307.

Kwok, K.W.H. \& Leung, K.M.Y. 2005. Toxicity of antifouling biocides to the intertidal harpacticoid copepod Tigriopus japonicus (Crustacea, Copepoda), effects of temperature and salinity. Marine Pollution Bulletin, 51: 830-837.

Leaño, E.M., Lio-Po, G.D., Nadong, L.A., Tirado, A.C., Sadaba, R.B. \& Guanzon, N.G. 2005. Mycoflora of the 'green water' culture system of tiger shrimp Penaeus monodon Fabricius. Aquatic Research, 36: 1581-1587.

Lee, J.J., Tietjen, J.H., Stone, R.J., Muller, W.A., Rullman, J. \& Mcenery, M. 1970. The cultivation and physiological ecology of members of salt marsh epiphytic communities. Helgoländer Wissenschaftliche Meeresuntersuchungen, 20: 136-156.

Lipton, A.P., Subhash, S.K., Paul Raj R. \& Anitha Rani A. 2003. Influence of environmental factors and microbial load on the spat settlement of pearl oyster, Pinctada fucata. First Indian Pearl Congress and Exposition. 
Central Marine Fisheries Research Institute, Cochin, pp. 52-54.

Liu, H., Zhou, Y., Xiao, W., Ji, L., Cao, X. \& Song, C. 2012. Shifting nutrient-mediated interactions between algae and bacteria in a microcosm. Evidence from alkaline phosphatase assay. Microbiological Research, 167: 292298.

Lloyd, D. 1974. Dark respiration. In: Stewart, W.D.P. (Ed.). Algal physiology and biochemistry. Blackwell, Oxford, pp. 505-529.

Loosanoff, V.L. \& Davis, H.C. 1963. Rearing of bivalve mollusks. Advances in Marine Biology, 1: 1-136.

Lourenço, S.O. 2006. Cultivos de microalgas marinhas, princípios e aplicações. Rima, São Carlos.

Maurin, N., Amblard, C. \& Bourdier, G. 1997. Phytoplanktonic excretion and bacterial reassimilation in an oligo-mesotrophic lake, molecular weight fractionation. Journal of Plankton Research, 19(8): 1045-1068.

McCracken, I.R. 1989. Purifying algal cultures a review of chemical methods. Proceedings of the Nova Scotian Institute of Science, 38: 145-168.

McCracken, A., Fidgeon, S., O'Brien, J.J. \& Anderson, D. 1976. An investigation of antibiotic and drug residues in fish. Journal of Applied Bacteriology, 40: 61-66.

Miller, C.A. \& Johnson, W.H. 1959. Preliminary studies on the axenic cultivation of a planarian (Dugesia). Annals of the New York Academy of Sciences, 77: 8792.

Møster, G. 1986. Bruk av antibiotika i fishkeoppdrett Sogn og Fjordane Distriktshogskole, 5800 Sogndal, Norway.

Müller, W.A. 1969. Auslösung der Metamorphose durch Bakterien bei den Larven von Hydractia echinata. Zoologische Jahrbücher. Abteilung für Anatomie, 86: 84-95.

Olafsen, J.A. 1993. The microbial ecology of fish aquaculture. In: Heen, K., Monahan, R.L. \& Utter, F. (Eds.). Salmon aquaculture. Fishing News Books, NHBS, London, pp. 166-175.

Pandey, P.K., Bharti, V. \& Kumar, K. 2014. Biofilm in aquaculture production. African Journal of Microbiology Research, 8: 1434-1443.

Pappas, G.D. \& Hoffman, H. 1952. The use of antibiotics for obtaining bacteria-free cultures of Euglena. Ohio Academy of Science, 52: 102-105.

Pedroso, M.S., Pinho, G.L.L., Rodrigues, S.C. \& Bianchini, A. 2007. Mechanism of acute silver toxicity in the euryhaline copepod Acartia tonsa. Aquatic Toxicology, 82: 173-180.

Pereira, D.J., Figueiredo, H.C.P., Carneiro, D.O. \& Leal, C.A.G. 2006. Concentração inibitória mínima de oxitetraciclina para isolados de Aeromonas hydrophila obtidos de diferentes fontes. Ciência e Agrotecnologia, 30: 1190-1195.

Pillay, T.V.R. \& Kutty, M.N. 2005. Aquaculture, principles, and practices. Blackwell Publishing, New Jersey.

Provasoli, L. \& Gold, K. 1962. Nutrition of the American Strain of Gyrodinium cohnii. Archiv für Mikrobiologie, 42: 196-203.

Provasoli, L., Hunter, S.H. \& Schatz, A. 1948. Streptomycin induced chlorophyll-less races of Euglena. Proceedings of the Society for Experimental Biology and Medicine, 69: 279-282.

Ray, C. 1966. Discussion remarks to 'round table, practical problems'. In: Norris, K.S. (Ed.). Whales, dolphins, and porpoises. University of California Press, Berkeley.

Rego, M., Silva E., Calazans N., Vogeley J., Nery R., Soares R. \& Peixoto S. 2012. Utilização de probiótico e antibiótico no cultivo de pós-larvas do camarão branco Litopenaeus vannamei. Atlântica, 34: 1237143.

Reid, P.C. \& Edwards, M. 2001. Plankton and climate. In: Steele, J. (Ed.). Encyclopedia of sciences. Academic Press, Oxford. pp. 2194-2200.

Rentachler, H.C., Nagy, R. \& Mouvomseff, G. 1941. Bactericidal effect of ultraviolet radiation. Journal of Bacteriology, 41: 745-774.

Ringelberg, J. \& Van Gool, E. 1998. Do bacteria, not fish, produce 'fish kairomone'? Journal of Plankton Research, 20(9): 1847-1852.

Riquelme, C.E. \& Avendaño-Herrera, R. 2003. Microalgae and bacteria interaction in the aquatic environment and their potential use in aquaculture. Revista Chilena de Historia Natural, 76: 725-736.

Roberts, M.H. 1972. Culture techniques for decapod crustacean larvae. In: Smith, W.L. \& Chanley, M.H. (Eds.). Culture of marine invertebrate animals. Plenum Press, New York.

Roberts, R.D., Kawamura, T. \& Handley, C.M. 2007. Factors affecting settlement of abalone (Haliotis iris) larvae on benthic diatom films. Journal of Shellfish Research, 26: 323-334.

Sande, M.A. \& Mandell, G.L. 1987. Drogas antimicrobianas - drogas antimicóticas e antivirais. In: Goodman, L. \& Gilman, A.G. (Eds.). As bases farmacológicas da terapêutica. AMGH Editora, Rio de Janeiro, pp. 799-807.

Schipp, G.R., Bosmans, J.M.P. \& Marshall, A.J. 1999. A method for hatchery culture of tropical calanoid copepods, Acartia spp. Aquaculture, 174: 81-88.

Schnack-Schiel, S.B. \& Isla, E. 2005. The role of zooplankton in the pelagic-benthic coupling of the Southern Ocean. Scientia Marina, 69(2): 39-55. 
Serrano, H.P. 2005. Responsible use of antibiotics in aquaculture. FAO Fisheries Technical Paper, Rome, 469: 97 pp.

Shaw, B.A., Harrison, R.J. \& Andersen, R.J. 1994. Evaluation of the copepod Tigriopus californicus as a bioassay organism for the detection of chemical feeding deterrents produced by marine phytoplankton. Marine Biology, 121: 89-95.

Sherr, B., Sherr, E., Andrew, T., Fallon, R. \& Newell, S. 1986. Trophic interactions between heterotrophic Protozoa and bacterioplankton in estuarine water analyzed with selective metabolic inhibitors. Marine Ecology Progress Series, 32: 169-179.

Shishlyannikov, S.M., Zakharova, Y.R., Volokitina, N.A., Mikhailov, I.S., Petrova, D.P. \& Likhoshway, Y.V. 2011. A procedure for establishing an axenic culture of the diatom Synedra acus subsp. radians (Kütz.) Skabibitsch. From Lake Baikal. Limnology and Oceanography Methods, 9: 478-484.

Silva, E.F.B., Fróes, C.N., Souza, D.M., Soares, R., Peixoto, S., Wasielesky, W. \& Ballester, E.L.C. 2012. Uso de probióticos na produção de pós-larvas de camarão-rosa. Pesquisa Agropecuária Brasileira, 47: 869-874.

Speck, R.S., Jarwetz, E. \& Gunnison, I.B. 1951. Studies on antibiotic synergism and antagonism. Archives of Internal Medicine Journal, 88: 166-174.

Spencer, C.P. 1952. On the use of antibiotics for isolating bacteria-free cultures of marine phytoplankton organisms. Journal of the Marine Biological Association of the United Kingdom, 31: 97-106.

Struhsaker, J.W., Hashimoto, D.Y., Girard, S.M., Prior, F.T. \& Cooney, T.D. 1973. Effect of antibiotics on survival of carangid fish larvae (Caranx mate), reared in the laboratory. Aquaculture, 2: 53-58.

Tang, K.W., Freund, C.S. \& Schweitzer, C.L. 2006. Occurrence of copepod carcasses in the lower Chesapeake Bay and their decomposition by ambient microbes. Estuarine, Coastal and Shelf Science, 68: 499-508.

Tartarotti, B. \& Torres, J.J. 2009. Sublethal stress: impact of solar UV radiation on protein synthesis in the copepod Acartia tonsa. Journal of Experimental Marine Biology and Ecology, 375: 106-113.

Tchan, Y.T. \& Gould, J. 1961. Use of antibiotics to purify blue-green algae. Nature, 192: 1276.

Torkildsen, L. \& Magnesen, T. 2004. Hatchery production of scallop larvae (Pecten maximus) survival in different rearing systems. Aquaculture International, 12: 489-507.

Trottet, A., Fouilland, E., Leboulanger, C., Lanouguère, E. \& Bouvy, M. 2011. Use of inhibitors for coastal bacteria and phytoplankton. Application to nitrogen uptake measurement. Estuarine, Coastal and Shelf Science, 93: 151-159.
Tuker, M. 1959. Inhibitory control of regeneration in nemertean worms. Journal of Morphology, 105: 569600.

Tungaraza, C., Brion, N., Rousseau, V., Baeyens, W. \& Goeyens, L. 2003. Influence of bacterial activities on nitrogen uptake rates determined by the application of antibiotics. Oceanologia, 45: 473-489.

Turner, J.T. 2015. Zooplankton fecal pellets, marine snow, phytodetritus, and the ocean's biological pump. Progress in Oceanography, 130: 205-248.

Ukeles, R. 1977. Unicellular plants. In: Kinne, O. (Ed.). Marine ecology, a comprehensive, integrated treatise on life in oceans and coastal waters. John Wiley \& Sons, New Jersey, pp. 368-466.

Uriarte, I., Parias, A. \& Castilla, J.C. 2001. Effect of antibiotic treatment during larval development of the Chilean scallop Argopecten purpuratus. Aquacultural Engineering, 25: 139-147.

Vasudevan, R. 2014. Biofilms, microbial cities of scientific significance. The Journal of Microbiology, 1: 1-16.

Vieira, A.A.H. 1977. Métodos de cultura de algas do plâncton marinho, estudos realizados nas regiões de Cananéia e de Ubatuba, SP. Boletim do Instituto Oceanográfico, 26: 303-338.

Walne, P.R. 1956. Bacteria in experiments on rearing oyster larvae. Nature, 178: 91.

Walne, P.R. 1958. The importance of bacteria in laboratory experiments on rearing the larvae of Ostrea edulis. Journal of the Marine Biological Association of the United Kingdom, 37: 415-425.

Walne, P.R. 1963. Observations on the food value of seven species of algae to the larvae of Ostrea edulis. I. Feeding experiments. Journal of the Marine Biological Association of the United Kingdom, 43: 767-784.

Walne, P.R. 1970. Culture of bivalve mollusks: 50 years' experience at Conwy. Fishing News Books, NHBS, London.

Wahl, M., Goecke, F., Labes, A., Dobretsov, S. \& Weinberger, F. 2012. The second skin, ecological role of epibiotic biofilms on marine organisms. Frontiers in Microbiology, 3: 292.

Wheeler, P.A. \& Kirchman, D.L. 1986. Utilization of inorganic and organic nitrogen by bacteria in marine systems. Limnology and Oceanography, 31: 9981009.

Wilkens, S.L. \& Maas, E.W. 2012. Development of a novel technique for axenic isolation and culture of thraustochytrids from New Zealand marine environments. Journal of Applied Microbiology, 112: 346-352.

Wollenberger, L., Halling-Sørensen, B. \& Kusk, K.O. 2000. Acute and chronic toxicity of veterinary antibiotics to Daphnia magna. Chemosphere, 40: 723-730. 
Wyban, J.A. \& Sweeney, J.N. 1991. Intensive shrimp production technology. The Oceanic Institute Shrimp Manual, Honolulu.

Yetka, J.E. \& Wiebe, W.J. 1974. Ecological application of antibiotics as respiratory inhibitors of bacterial populations. Journal of Applied Microbiology, 28: 10331039.

Ying, G. \& Kookana, R.S. 2007.Triclosan in wastewaters and biosolids from Australian wastewater treatment plants. Environment International, 33: 199-205.

Yoshimura, E., Nogata, Y. \& Sakaguchi, I. 2006. Simple methods for mass culture of barnacle larvae. Sessile Organisms, 23(2): 39-42.

Youn, J-Y. \& Hur, S.B. 2007. Antibiotics and their optimum concentration for axenic culture of marine microalgae. Algae, 22: 229-234.
Zaror, L., Collado, L., Bohle, H., Landskron, E., Montaña, J. \& Avendano, F. 2004. Saprolegnia parasitica en salmones y truchas del sur de Chile. Archivos de Medicina Veterinaria, 36: 71-78.

Zhou, W., Li, Y., Min, M., Hu, B., Chen, P. \& Ruan, R. 2011. Local bioprospecting for high-lipid producing microalgal strains to be grown on concentrated municipal wastewater for biofuel production. Bioresource Technology, 102: 6909-6919.

Received: 15 September 2017; Accepted: 4 April 2019

\section{SUPPLEMENTARY DATA}

Annex 1. Main antimicrobials (prokaryote inhibitors) used in plankton cultures between 1940 and 2016.

\begin{tabular}{|c|c|c|c|c|}
\hline \multirow{2}{*}{ Antimicrobials } & \multirow{2}{*}{$\begin{array}{l}\text { Used between } 1940 \\
\text { and } 2016(\%)\end{array}$} & \multicolumn{3}{|c|}{ Years } \\
\hline & & 1940-1959 & 1960-1989 & 1990-2016 \\
\hline Aerosporin & 0.2 & & $\mathrm{X}$ & \\
\hline Amoxicillin & 0.9 & & & $\mathrm{X}$ \\
\hline Ampicillin (Binotal $\left.{ }^{\circledR}\right)$ & 1.6 & & $\mathrm{X}$ & $\mathrm{X}$ \\
\hline Basitracin & 0.7 & $\mathrm{X}$ & & \\
\hline Carbenicillin $\left(\right.$ Geopen $\left.^{\circledR}\right)$ & 0.5 & & $\mathrm{X}$ & \\
\hline Cefazolin & 0.2 & & & $\mathrm{X}$ \\
\hline Cefuroxime & 0.3 & & & $\mathrm{X}$ \\
\hline Cephalothin (Keflin ${ }^{\circledR}$ ) & 0.5 & & $\mathrm{X}$ & \\
\hline Chloramphenicol (Chloromycetin ${ }^{\circledR}$ ) & 9.5 & $\mathrm{X}$ & $\mathrm{X}$ & $\mathrm{X}$ \\
\hline Chlortetracycline (Aureomycin ${ }^{\circledR}$ ) & 3.2 & $\mathrm{X}$ & $\mathrm{X}$ & $\mathrm{X}$ \\
\hline Ciprofloxacin & 1.4 & & & $\mathrm{X}$ \\
\hline Colomicin & 0.5 & & $\mathrm{X}$ & \\
\hline Dihydroestreptomicine & 2.9 & $\mathrm{X}$ & $\mathrm{X}$ & $\mathrm{X}$ \\
\hline Doxycycline & 0.2 & & & $\mathrm{X}$ \\
\hline Enrofloxacin & 0.5 & & & $\mathrm{X}$ \\
\hline Erythromycin (Clarithromycin ${ }^{\circledR}$, Iloticina ${ }^{\circledR}$ ) & 3.2 & $\mathrm{X}$ & $\mathrm{X}$ & $\mathrm{X}$ \\
\hline Florfenicol (Nuflor ${ }^{\circledR}$ ) & 0.3 & & & $\mathrm{X}$ \\
\hline Furaltadone & 0.5 & & & $\mathrm{X}$ \\
\hline Furazilidone & 0.2 & & & $\mathrm{X}$ \\
\hline Gentamicin & 1.4 & & $\mathrm{X}$ & $\mathrm{X}$ \\
\hline Gramicidin & 0.7 & $\mathrm{X}$ & & \\
\hline Imipenem & 0.7 & & & $\mathrm{X}$ \\
\hline Kanamycin & 1.4 & & & $\mathrm{X}$ \\
\hline Levofloxacin & 0.2 & & & $\mathrm{X}$ \\
\hline Lincomycin & 0.5 & & & $\mathrm{X}$ \\
\hline Neomycin & 4.3 & $\mathrm{X}$ & $\mathrm{X}$ & $\mathrm{X}$ \\
\hline Nitrofurantoin & 0.2 & & $\mathrm{X}$ & \\
\hline Norfloxacin & 0.9 & & & $\mathrm{X}$ \\
\hline Novobiocin & 0.7 & $\mathrm{X}$ & $\mathrm{X}$ & \\
\hline Ofloxacin & 0.2 & & & $\mathrm{X}$ \\
\hline Oxytetracycline & 4.1 & $\mathrm{X}$ & & $\mathrm{X}$ \\
\hline
\end{tabular}


Continuation

\begin{tabular}{|c|c|c|c|c|}
\hline \multirow{2}{*}{ Antimicrobials } & \multirow{2}{*}{$\begin{array}{c}\text { Used between } 1940 \\
\text { and } 2016(\%)\end{array}$} & \multicolumn{3}{|c|}{ Years } \\
\hline & & 1940-1959 & 1960-1989 & 1990-2016 \\
\hline Penicillin & 23.9 & $\mathrm{X}$ & $\mathrm{X}$ & $\mathrm{X}$ \\
\hline Polymyxin-B & 1.6 & $\mathrm{X}$ & $\mathrm{X}$ & \\
\hline Pyrimethamine & 0.2 & & & $\mathrm{X}$ \\
\hline Rifampicin & 0.5 & & & $\mathrm{X}$ \\
\hline Ristocetin & 0.2 & & $\mathrm{X}$ & \\
\hline Roxithromycin & 0.3 & & & $\mathrm{X}$ \\
\hline Spiramycin & 0.2 & & $\mathrm{X}$ & \\
\hline Streptomycin & 18.5 & $\mathrm{X}$ & $\mathrm{X}$ & $\mathrm{X}$ \\
\hline Sulfamerazine & 0.5 & & $\mathrm{X}$ & \\
\hline Sulfamethoxazole & 1.1 & & & $\mathrm{X}$ \\
\hline Sulfonamide, (Sulfadiazine ${ }^{\circledR}$, Sulfadimethoxine ${ }^{\circledR}$ ) & 1.1 & & $\mathrm{X}$ & $\mathrm{X}$ \\
\hline Tetracycline & 3.2 & $\mathrm{X}$ & $\mathrm{X}$ & $\mathrm{X}$ \\
\hline Thiamphenicol & 0.5 & & & $\mathrm{X}$ \\
\hline Triclocarban & 0.3 & & & $\mathrm{X}$ \\
\hline Trimethoprim & 2.0 & & & $\mathrm{X}$ \\
\hline Trisulfapyrimidine (Triple sulfa ${ }^{\circledR}$ ) & 0.2 & & $\mathrm{X}$ & \\
\hline Tylosin & 0.9 & & & $\mathrm{X}$ \\
\hline Vancomycin & 0.9 & $\mathrm{X}$ & $\mathrm{X}$ & $\mathrm{X}$ \\
\hline
\end{tabular}

Annex 2. Inhibiting concentrations $\left(\mathrm{g} \mathrm{L}^{-1}\right)$ of the five most frequently cited antibiotics for different bacterial strains (modified from Berland \& Maestrini, 1969; Lourenço, 2006). *Partial activity.

\begin{tabular}{|c|c|c|c|c|c|}
\hline \multirow{2}{*}{ Bacterioplakton species } & \multicolumn{5}{|c|}{ Antibiotic } \\
\hline & Penicillin & Streptomycin & Chloramphenicol & Oxytetracycline & Neomycin \\
\hline Action & Gram + & Gram \pm & Gram \pm & Gram \pm & Gram $\pm *$ \\
\hline Pseudomonas aestumarina & 4 & $>10$ & 1 & 2 & 0.02 \\
\hline Psedomonas cruciviae & 0.001 & 0.03 & 0.002 & 0.05 & 0.03 \\
\hline Pseudomonas marinoglutinosa & 2.5 & 4 & 0.15 & 1 & 1 \\
\hline Pseudomonas riboflavina & 0.05 & 0.02 & 0.025 & 0.02 & 0.02 \\
\hline Pseudomonas stereotropis & 0.00025 & 0.025 & 0.002 & 1.75 & 0.05 \\
\hline Vibrio algosus & 1.75 & 0.003 & 0.01 & 1.5 & 2 \\
\hline Vibrio phytoplanktis & 0.015 & 0.08 & 0.0015 & 1.7 & 1.75 \\
\hline Agarbacterium mesentericus & 3 & 0.02 & 0.005 & 1.5 & 0.03 \\
\hline Xanthomonas & 0.03 & $>10$ & 0.001 & 1 & 1.5 \\
\hline Achromobacter parvulus & 0.001 & $>10$ & 0.002 & 1,5 & 1.25 \\
\hline Achromobacter stationis & 0.00025 & 0.015 & 0.0015 & 0.05 & 0.01 \\
\hline Achromobacter stenohalis & 0.05 & 0.005 & 0.0015 & 0.02 & 0.015 \\
\hline Flavobacterium aquatile & 0.05 & 0.04 & 0.03 & 1.25 & $>10$ \\
\hline Flavobacterium lutescens & 1 & $>10$ & 0.075 & 0.075 & $>2.1$ \\
\hline Flavobacterium peregrinum & 0.002 & 10 & 0.005 & 10 & 0.01 \\
\hline Micrococcus & 0.015 & 0.025 & 0.002 & 2.5 & 4 \\
\hline Staphylococcus aureus & 0.007 & 0.02 & 0.005 & 1.5 & 0.03 \\
\hline Antibiotic & \multicolumn{5}{|c|}{ Mechanism of action } \\
\hline Penicillin G & \multicolumn{5}{|c|}{$\begin{array}{l}\text { interferes with the synthesis of bacterial cell wall by inhibiting enzymes involved in } \\
\text { transpeptidation, making them fragile and subject to rupture }\end{array}$} \\
\hline Streptomycin & \multicolumn{5}{|c|}{$\begin{array}{l}\text { interrupts bacterial growth by binding to the } 16 \mathrm{~S} \text { rARN subunit, preventing the synthesis } \\
\text { of polypeptide chains }\end{array}$} \\
\hline Chloramphenicol & \multicolumn{5}{|c|}{$\begin{array}{l}\text { inhibits the activity of the enzyme peptidyl transferase, preventing the coupling of } \\
\text { amino-acyl-rARN to the site of the 50S subunit of the ribosome, preventing bacterial } \\
\text { protein synthesis }\end{array}$} \\
\hline Oxytetracycline & \multicolumn{5}{|c|}{$\begin{array}{l}\text { inhibits cell growth by preventing translation: coupled to the part of the } 16 \mathrm{~S} \text { subunit of } \\
30 \mathrm{~S} \text { ribosomes and prevents the action of amino-acyl-tARN in the site A of organelle }\end{array}$} \\
\hline Neomycin & \multicolumn{5}{|c|}{$\begin{array}{l}\text { prevents the translocation site acyl peptidyl-tARN to the site } \mathrm{A} \text { to site } \mathrm{P} \text { resulting in } \\
\text { mRNA reading errors which lead to the interruption of protein synthesis }\end{array}$} \\
\hline
\end{tabular}


Annex 3. List of important published papers on the use of antimicrobials in culture/production and in hypothesis testing to obtain a bacteria-free medium. *Unspecified.

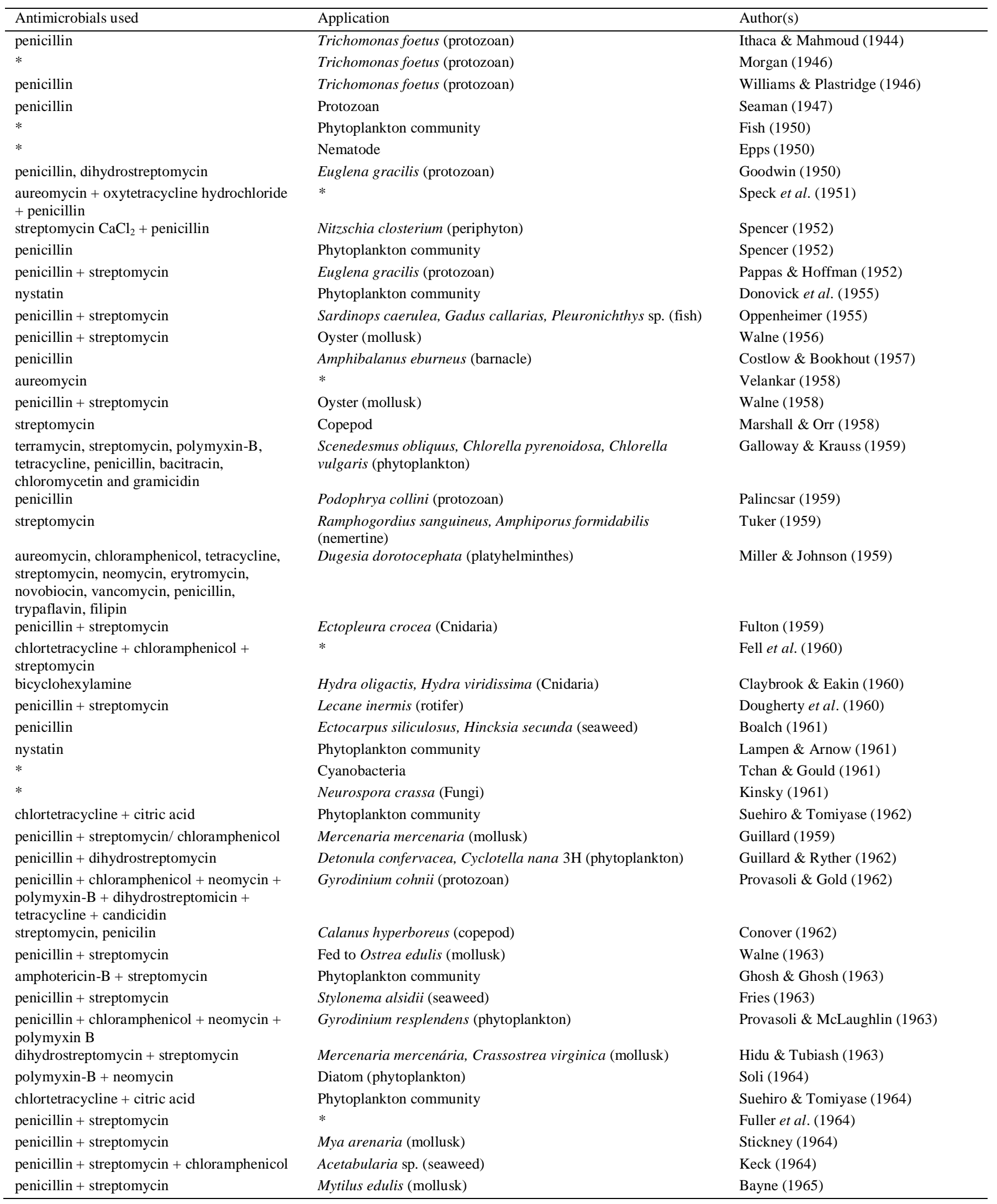


Continuation

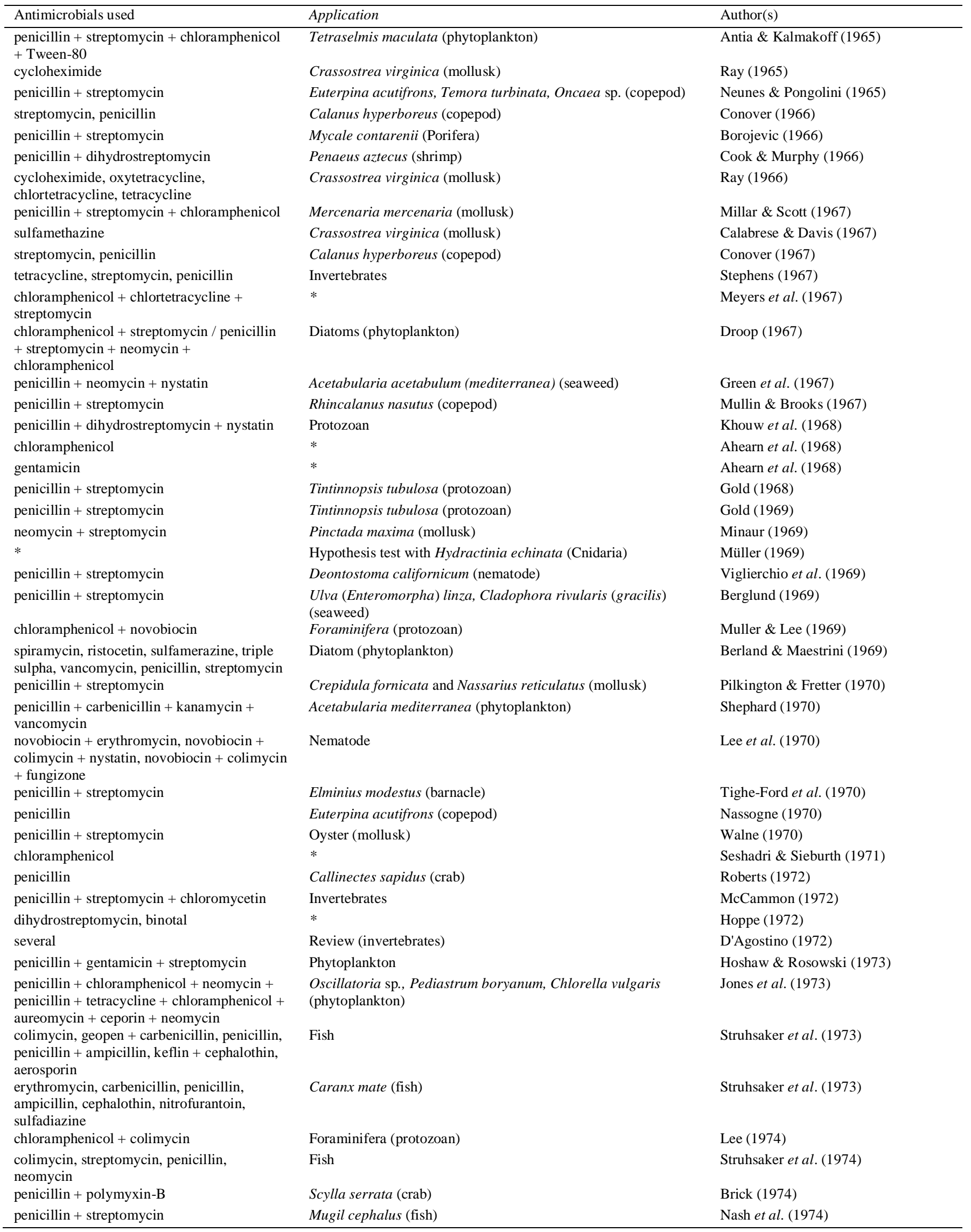


Continuation

\begin{tabular}{|c|c|c|}
\hline Antimicrobials used & Application & Author(s) \\
\hline chloramphenicol & Fish & Struhsaker et al. (1975) \\
\hline * & Euglena gracilis, Mycobacterium phlei (protozoan) & Ebringer et al. (1976) \\
\hline penicillin + streptomycin + chloramphenicol & Phytoplankton community & Vieira (1977) \\
\hline $\begin{array}{l}\text { + neomycin + neomycin + cycloheximide } \\
\text { chloramphenicol + streptomycin }+ \text { penicillin }\end{array}$ & Cancer magister (crab) & Fisher \& Nelson (1978) \\
\hline streptomycin + chloramphenicol & Phytoplankton community & Tipper \& Wright (1979) \\
\hline $\begin{array}{l}\text { dihydrostreptomycin }+ \text { neomycin }+ \text { penicillin } \\
+ \text { amphotericin-B }\end{array}$ & Gonyaulax catenella, Gonyaulax excavata (protozoan) & Divan \& Schnoes (1982) \\
\hline penicillin + streptomycin + chloramphenicol & Dictyosiphon foeniculaceus (seaweed) & Saga \& Sakai (1982) \\
\hline $\begin{array}{l}\text { penicillin, vancomycin, chloramphenicol/ } \\
\text { vancomycin + penicillin }\end{array}$ & Hypothesis test & Sherr et al. (1986) \\
\hline chloramphenicol & Brachionus plicatilis (rotifers) & Benavente \& Gatesoupe (1988) \\
\hline $\begin{array}{l}\text { ampicillin, carbenicillin, cephaloridine, } \\
\text { cephalothin, chloramphenicol, } \\
\text { chlortetracycline, colistin, erythromycin, } \\
\text { gentamicin, kanamycin, lincomicin, nalidixic } \\
\text { acid, neomycin, novobiocin, rifampin, } \\
\text { streptomycin, triple sulfa, tetracycline, } \\
\text { trimethoprim, vancomicin }\end{array}$ & Seaweed & Bradley et al. (1988) \\
\hline $\begin{array}{l}\text { penicillin + streptomycin + polymyxin B + } \\
\text { chloramphenicol }\end{array}$ & Seaweed & Tatewaki (1989) \\
\hline sulfamethazine & Hypothesis test with Arachnoides placenta (Echinodermata) & Chen \& Run (1980) \\
\hline$*$ & Review (phytoplankton) & McCracken (1989) \\
\hline $\begin{array}{l}\text { oxolinic acid, kanamycin, erythromycin, } \\
\text { penicillin, streptomycin }\end{array}$ & Brachionus plicatilis (rotifers) & Munro et al. (1995) \\
\hline $\begin{array}{l}\text { penicillin + streptomycin + polymyxin-B + } \\
\text { chloramphenicol }\end{array}$ & Gymnodinium (protozoan) & Hasui et al. (1995) \\
\hline Penicillin + streptomycin + chloramphenicol & Phytoplankton & González et al. (1995) \\
\hline framycetin + amoxicillin & Prorocentrum cordatum (protozoan) & Grzebyk et al. (1997) \\
\hline streptomycin & Hypothesis test & Maurin et al. (1997) \\
\hline$*$ & Amphibalanus amphitrite (barnacle) & Thomason et al. (1998) \\
\hline$*$ & Coscinodiscus wailesii (phytoplankton) & Nagai et al. (1998) \\
\hline ampicillin & Hypothesis test & Ringelberg \& Van Gool (1998) \\
\hline$*$ & Amphibalanus reticulatus (barnacle) & Lee et al. (1999) \\
\hline chloramphenicol & Nodipecten nodosus (mollusk) & $\operatorname{Bem}(1999)$ \\
\hline $\begin{array}{l}\text { kanamycin, crys-4, streptomycin, } \\
\text { chloramphenicol }\end{array}$ & Pinctada fucata (mollusk) & $\begin{array}{l}\text { Dharmaraj \& Shahmugasundaram } \\
\text { (1999) }\end{array}$ \\
\hline penicillin + streptomycin + neomycin & Hypothesis test & Middelburg \& Nieuwenhuize (2000a) \\
\hline penicillin + streptomycin + neomycin & Hypothesis test & Middelburg \& Nieuwenhuize, 2000b \\
\hline $\begin{array}{l}\text { penicillin }+ \text { streptomycin }+ \text { neomycin }+ \\
\text { cycloheximide }\end{array}$ & Hypothesis test & DeLorenzo et al. (2001) \\
\hline streptomycin + furaltadone & Argopecten purpuratus (mollusk) & Riquelme et al. (2001) \\
\hline chloramphenicol & Argopecten purpuratus (mollusk) & Uriarte et al. (2001) \\
\hline flumequine, oxytetracycline & Brachionus plicatilis (rotifers) & Göksan \& Gökpinar (2001) \\
\hline$*$ & Rotifers & Dhert et al. (2001) \\
\hline
\end{tabular}


Continuation

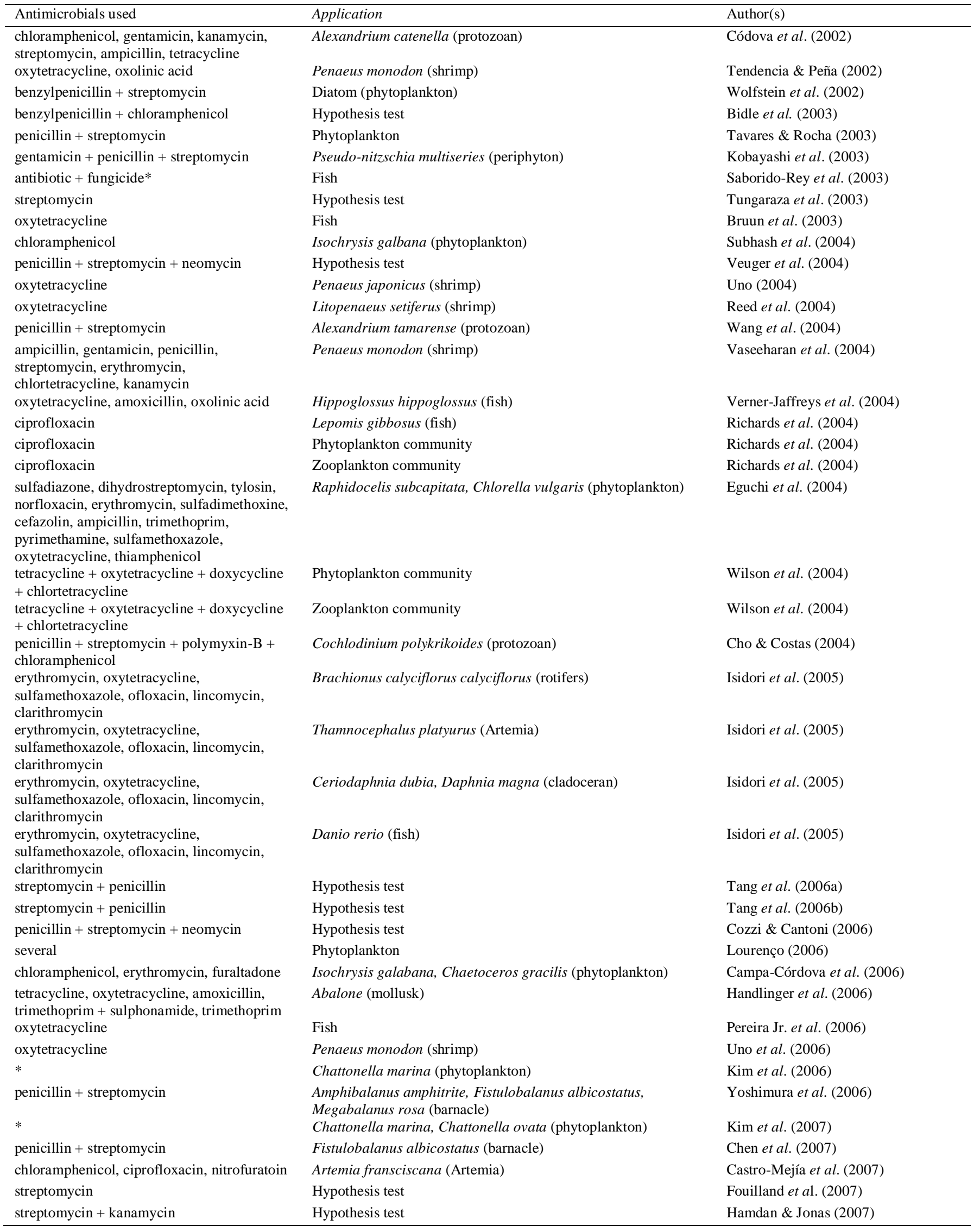


Continuation

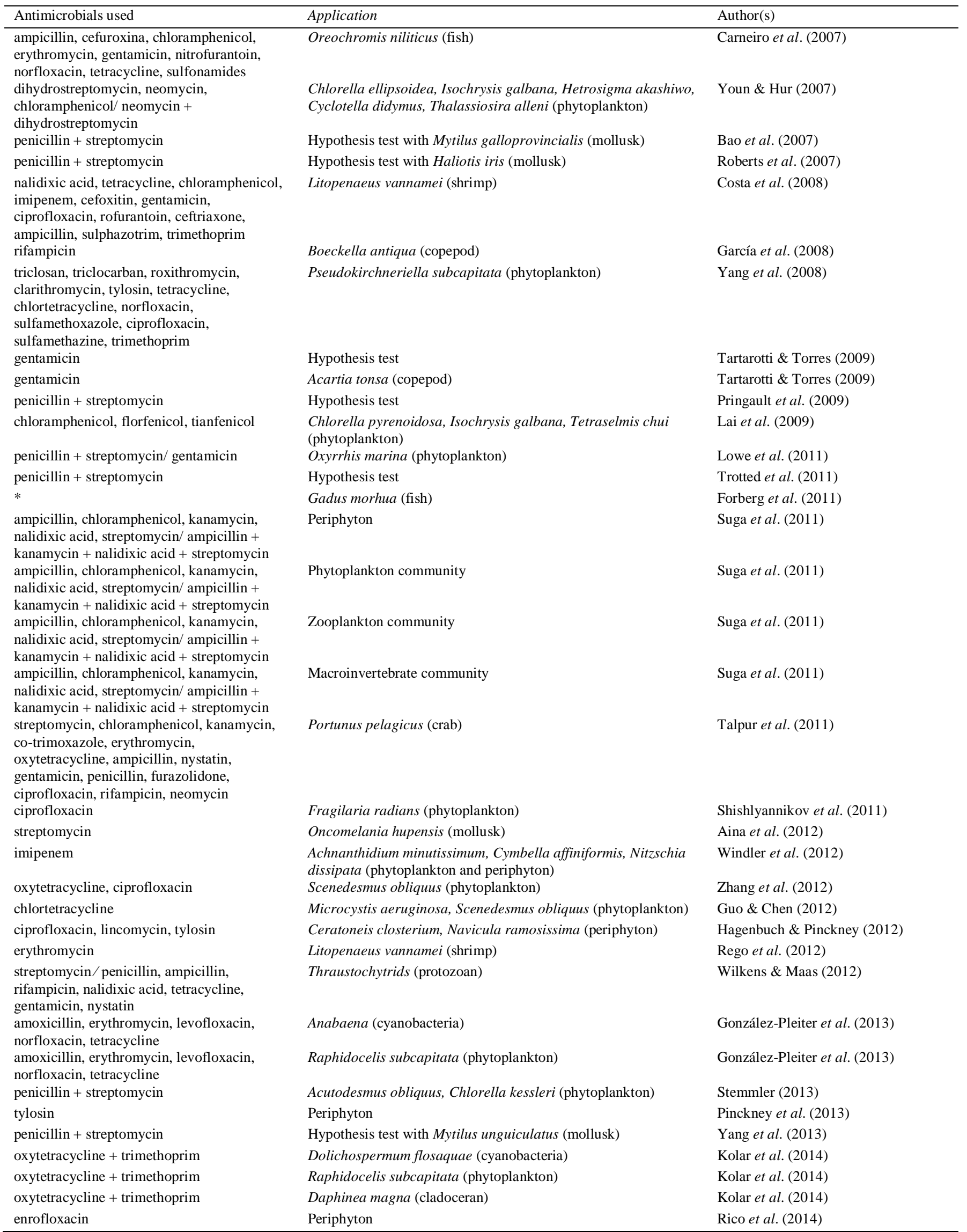


Continuation

\begin{tabular}{|c|c|c|}
\hline Antimicrobials used & Application & Author(s) \\
\hline enrofloxacin & Phytoplankton community & Rico et al. (2014) \\
\hline enrofloxacin & Zooplankton community & Rico et al. (2014) \\
\hline enrofloxacin & Invertebrates & Rico et al. (2014) \\
\hline ciprofloxacin, sulfamethoxazole & Periphyton & Johansson et al. (2014) \\
\hline $\begin{array}{l}\text { penicillin + vancomycin/ penicillin + } \\
\text { streptomycin/ neomycin/ penicillin }+ \\
\text { streptomycin + chloramphenicol }\end{array}$ & Isochrysis galbana, Conticribra weissflogii (phytoplankton) & Agostini (2014) \\
\hline $\begin{array}{l}\text { penicillin + streptomycin + neomycin/ } \\
\text { penicillin + streptomycin }\end{array}$ & Acartia tonsa (copepod) & Agostini (2014) \\
\hline streptomycin + ampicillin & Limacina helicina (mollusk) & Howes et al. (2014) \\
\hline penicillin + streptomycin + neomycin & Acartia tonsa (copepod) & Agostini et al. (2016) \\
\hline
\end{tabular}

